\title{
PORT SYSTEM EVOLUTION - THE CASE OF LATIN AMERICA AND THE CARIBBEAN
}

This is the pre-published version of the text. The final published paper can be found at:

Wilmsmeier, G, Monios, J, Pérez-Salas, G. (2014). Port system evolution: the case of Latin America and the Caribbean. Journal of Transport Geography. 39: 208-221.

DOI: $10.1016 / j . j t r a n g e o .2014 .07 .007$

\begin{abstract}
The explosion of global container trade in the last two decades has significantly influenced the port geography of Latin America \& the Caribbean (LAC), leading to a concentration of container traffic at selected ports. Theory suggests that, as port systems become mature, they tend to deconcentration, partly due to the emergence of secondary ports. Previous research has examined the region's dominant ports, but an unanswered research question is how the evolution of this port system is influencing and being influenced by the actions of those ports currently occupying a secondary rank in the LAC port hierarchy.
\end{abstract}

The methodology is based primarily on analysis of time series data on container movements between 1997 and 2012, revealing patterns of cargo flows and transhipment location choices. The institutional context of devolution processes and new investments in the region provides additional insight into the performance of selected ports. From a theoretical perspective, this analysis is situated within the context of recent institutional approaches that examine the port's ability to act through critical moments and junctures, in order to deepen understanding of which of the various factors influencing port system deconcentration are the most sensitive to successful institutional adaptations.

Results show that the manufacturing of strategic locations can be successful and may have driven the emergence of secondary ports in the LAC system. This finding demonstrates how path dependence can be challenged by new developments, the identification and success of which are nevertheless contingent on factors such as the first mover advantage, port planning regimes and diversification of port roles. The paper identifies some of the key factors influencing the transition of a port system from concentration at a few dominant ports to a deconcentrated system of primary and secondary ports, which can be applied to other port systems in future research.

Keywords: container port development; deconcentration; decentralisation; peripherality; Latin America; liner shipping; secondary ports; regional ports; devolution; institutions 


\section{Introduction}

Ports and port systems have been studied by geographers for several decades, as their evolution can be observed via spatial developments of nodes and corridors, as well as exhibiting processes of concentration and centralisation of trade and traffic flows. Numerous models have been developed to systematise and classify port system evolution, proceeding from the traditional spatial analyses of port expansion (Bird, 1963; Taaffe et al., 1963; Rimmer, 1967; Hoyle, 1968; Hayuth, 1981; Barke, 1986; Van Klink, 1998) to the more recent focus on port competition through hinterland accessibility, such as the concept of port regionalization as one possible pathway in port system evolution (Notteboom and Rodrigue, 2005; Monios and Wilmsmeier, 2012). Other discussions include the competition in the maritime foreland, focusing on intermediate transhipment hubs and the structure of maritime services (Sanchez and Wilmsmeier, 2006; Rodrigue and Notteboom, 2010).

This paper examines the Wilmsmeier and Notteboom (2011) four-phase model capturing the influence of the evolution of liner shipping networks on port development. The interest of this paper is the transition from phase three (mature hub-and-spoke networks, port devolution, penetration of international operators) to phase four (the rise of direct services, current hubs undermined and the rise of new secondary hub-and-spoke networks). The many influences on this transition are not yet fully understood. The goal of this paper is, therefore, to perform a detailed analysis of a representative case in order to develop a framework for systematic analysis of this important phase of system evolution.

One of the key observations in previous analyses is the efforts of secondary ports to counteract the concentration of container traffic at a few large gateways, seeking ways to overcome their peripheral status and increase their access to global trade routes. Wang and $\mathrm{Ng}$ (2011) identified this category of secondary ports in an analysis of the Chinese port system, yet they noted that such ports have not received sufficient attention in the literature. A similar finding was made by Wilmsmeier and Monios (2013) in an analysis of the UK port system. It is thus important for the key drivers of this development to be identified and explored in more detail. The goal of this paper to systematise them will be aided by applying recent theoretical approaches (particularly Jacobs and Notteboom, 2011) to an analysis of the transition of the Latin American and the Caribbean (LAC) port system from phase three to phase four. From this theoretical perspective, the paper aims to understand the evolution of maritime networks and the autopoietic nature of port development as secondary ports seek to reposition themselves within emerging feeder markets through a variety of proactive and reactive strategies that involve different actors within a complex institutional environment. 
The analysis will chart the progress of the LAC system moving through these phases and look for the critical moments, according to the rationale that such critical moments are likely to be similar in other port systems, hence these findings will be transferable to other contexts.

The methodology includes both quantitative and qualitative analysis. The former is based on a UN-ECLAC database covering 180 container ports across the LAC port system from the years 1997-2012. Maps and charts are used to examine processes of port throughput concentration and deconcentration over time, transhipment location choices and decentralisation through the success of emerging secondary ports, from both a macro system perspective (the entire LAC system) and a sub-regional perspective (divided into coastal ranges). While numerical measures of concentration applied to the port sector such as the Herfindahl-Hirschman index (HHI) and the Gini coefficient are calculated and provided in the appendix, the analysis in this paper does not rely on them. Both are measures of concentration or equality in a system, yet care must be taken interpreting such indices as they can be misleading without further information. Understanding of a port system cannot be derived from such aggregated indices and requires close analysis of changes in throughput at individual ports over time, particularly when new ports enter the system during the time period under study. Moreover, appreciation of qualitative data relating to port development and infrastructure investment strategies at primary and secondary LAC ports are required; these are examined through discussion of selected examples. In order to bring the quantitative and qualitative findings together, the institutional literature provides assistance through the adoption of a theoretical perspective that builds on recent institutional approaches that examine the port's ability to act through critical moments and junctures.

The following two sections examine peripherality, the role of concentration of container service provision at hub ports, port development strategies and the importance of liner network connectivity. Port system evolution models are discussed and the need to understand the transition from phase three to phase four of the Wilmsmeier and Notteboom (2011) model is established, as well as the rationale for the selection of the LAC case. A discussion on the port's ability to act in the context of recent institutional literature is raised in order to provide a framework for identifying the critical moments influencing the transition from phase three to four. The LAC port system and its evolution are analysed in section five, while section six reviews the institutional setting relating to port devolution and the development of new ports in the LAC system. Section seven summarises the findings into a framework of critical moments, systematising the key influences and section eight concludes with suggestions for future research deriving from this framework. 


\section{Peripherality and concentration}

Issues faced by peripheral regions include high transport costs and an inability to generate economies of scale and density (Nijkamp, 1998). In the context of maritime trade peripherality is particularly driven not by geographic but by economic distance, reflected in connectivity and market structures (Wilmsmeier, 2010, Sanchez and Wilmsmeier 2011). This is relevant in the context of the increasing integration and reduction of economic, legal and practical barriers between countries within supranational trading blocs and in the Latin American case related to the physical integration initiatives that aim at increasing regional integration based on infrastructure development. Furthermore, a distinction may be drawn between peripheral regions within a country and peripheral countries. Nijkamp (1998) noted that "a system of regions is much more an open trade system without customs or institutional barriers. Thus, competitiveness plays a crucial role in regional development [and] . . factor mobility tends to be much higher between regions" (p.8). The reduction of internal barriers can lead to a concentration of container traffic at fewer, larger gateway ports, but also to a diversification and decentralisation of port traffic through an extension of port hinterlands as a result of infrastructure development. This paper aims to understand the drivers for a multiple gateway approach that would lead to decentralisation and provide secondary ports with a greater role, while simultaneously providing increased opportunities for peripheral trade.

Numerous studies on port system development exist, evolving from the traditional spatial analyses of port expansion and upgrading of berthing and handling facilities (Bird, 1963; Taaffe et al., 1963; Rimmer, 1967; Hoyle, 1968; Hayuth, 1981; Barke, 1986; Van Klink, 1998) to the more recent focus on port competition through hinterland accessibility, such as the concept of port regionalization as one possible pathway in port system evolution (Notteboom and Rodrigue, 2005; Monios and Wilmsmeier, 2012). Other influences on port system evolution include the competition in the maritime foreland, focusing on intermediate transhipment hubs and the structure of maritime services (Sanchez and Wilmsmeier, 2006; Rodrigue and Notteboom, 2010), and in particular the role of the concentration of liner services (e.g. Frémont \& Soppé, 2007; Lee et al., 2008; Wang \& Ducruet, 2012).

As a port system moves towards concentration, particularly for unitised cargo, significant challenges to hinterland infrastructure become apparent. Ducruet et al. (2009; p.359) argued that "concentration stems from the path-dependency of large agglomerations", while drivers of deconcentration include "new port development, carrier selection, global operation 
strategies, governmental policies, congestion, and lack of space at main load centres." According to Barke (1986) and Hayuth (1981), port system concentration will eventually reach its limits and invert, leading to a process of deconcentration, a phenomenon discussed by Slack and Wang (2002), Notteboom (2005), Frémont and Soppé (2007). While network development and port choice are based on many factors, the port's ability to "steer their own future" (Olivier and Slack, 2006; p.1414) can exert some influence. Ports can take on "the challenge of the periphery" (Barke, 1986; Hayuth, 1981; Slack and Wang, 2002); in particular, secondary ports can take advantage of wider trends such as the limits of concentration and reposition themselves to take advantage of a network that may be changing from an outdated system of hubs to new structures.

Wilmsmeier and Monios (2013) argued that existing theory falls short of differentiating between deconcentration that emerges upon failure of a system in a reactive manner, deconcentration that materializes from proactive port development strategies, and deconcentration that emerges from new economic and industrial development. Thus the drivers of deconcentration processes can be related not only to the port system, but also to the transport system (i.e. hinterland infrastructure and carrier strategy) and the economic system (e.g. logistics strategies, economic development) (Wilmsmeier and Monios, 2013; Wilmsmeier and Sanchez, 2010; Robinson, 2002).

\section{Liner shipping networks and port system evolution}

Port operators and shipping lines have both exhibited strong concentration processes as well as increasing vertical integration. In 2012, the top ten carriers controlled approximately $63 \%$ of the world container shipping capacity (Alphaliner, 2012), while the top ten port terminal operators handled approximately 36 per cent of total container throughput (of which 26.5 per cent was just the top four), measured in "equity TEU" (Drewry, 2012). ${ }^{1}$ Strategic alliances between them have exerted a profound influence on maritime network structure and also on a region's integration in the global maritime transport network. These developments have, to a certain extent, made port development dependent on network strategies of global players. The location of a port within the network influences the competitiveness of trade through that port and subsequently raises important questions regarding what determinants lead to the configuration of current networks and how these could be influenced.

\footnotetext{
${ }^{1}$ The "equity TEU" concept was devised by Drewry as a more accurate way than simple TEU throughput to account for the fact that some terminal operators have shares in each other.
} 
The development of liner shipping networks is primarily driven by the demand for containerised transport, depending on the strategies of shipping companies and the demand of shippers for specific service characteristics. As such, the location of a port or a region within the global liner shipping network is determined by the density of trade flows to and from a specific port or region. These factors then become the determinants of the service frequency, loading capacity, number of port calls per roundtrip and transhipment or relay strategies (Fagerholt, 2004).

Port selection can be based on several criteria, from physical characteristics and geographical location to port efficiency, strategic carrier considerations and hinterland access (Wilmsmeier and Notteboom, 2011). Magala and Sammons (2008) argued that port choice is a by-product of the choice of logistics pathway. Thus port choice becomes more a function of the overall network cost and performance. From the carrier's perspective, the economies of scale, scope and density in shipping, port operations and inland operations would favour a very limited number of load centres in a region (Cullinane and Khanna, 2000; Frémont and Soppé, 2007).

Wilmsmeier and Notteboom (2011) proposed a generic four-phase model of the evolution of liner shipping networks, which can be used as a more qualitative holistic model for the evolving role of the port, as opposed to previous spatial models:

First phase. The liner shipping network is determined by point-to-point direct services with a strong local or regional orientation. The liner service network is highly regional in orientation and interconnectivity to the overseas markets is poor. Government involvement in the port sector is typically high while at the same time international market players (shipping lines and terminal operators) face limited possibilities to enter the region;

Second phase. The region and the market players seek a higher connectivity to overseas markets by consolidating cargo in an intermediate hub. The first tendencies towards a hub-and-spoke network emerge. The evolving liner service network configuration increases the dependency of the port system on indirect services via the hub, while direct regional services start to lose their importance. The growing connectivity of the port system to overseas markets increases the region's attractiveness to shipping lines and international port operators. The rising pressure on port infrastructures and the need for a professional and commercial approach to market dynamics urges government bodies to revise their port policy. Often, the local/regional/national government will seek the startup of a port devolution process to face the mounting infrastructural and operational port challenges linked to the opening up of the region to the world market. The resulting changes in the port governance and policy framework enable international stevedoring groups and shipping lines to access key assets in the local ports and to seek control over terminal operations. 
Third phase. Port traffic growth leads to a further outreach of the hub-and-spoke network and the inclusion of new ports in this pattern. International port operators further penetrate into the market and state intervention in ports is strongly reduced. Main lines are growing and smaller regional services start to develop again in a secondary network.

Fourth phase. The market size of specific ports has grown to such an extent that shipping lines can now offer direct services from these ports to overseas regions. The hub sees its functional position undermined. In view of maintaining its role in the network, the hub will seek liner service connections to smaller ports in the region which still lack connectivity to overseas market. Consequently, the terminal activity in the hub shifts in geographical terms and a new secondary hub-and-spoke network emerges involving other gateway ports.

It can be seen from previous research (Wilmsmeier, 2013), and will be clearly demonstrated from the data analysis elaborated in section 5 of this paper, that the LAC port system is at phase three. New ports are emerging (Pérez and Ulloa, 2010; Sánchez and Ulloa, 2007), a hub-and-spoke pattern is mature and smaller regional services are developing in a secondary network (Wilmsmeier, 2013; Wilmsmeier and Sánchez, 2010). The goal of this paper is to explore and systematise how systems move from phase three to four, hence the selection of the LAC case. In particular, a topic of rising importance in port geography is the drivers of and constraints on secondary port development (Wang and $\mathrm{Ng}, 2011$; Wilmsmeier and Monios, 2013). However, in order to understand how secondary ports act under such conditions, a more complex and nuanced understanding of the port's ability to act is required, calling for an appreciation of the institutional literature.

\section{The institutional context of port development}

One basis for distinguishing between the shipping and port subsystems remains the fact that the constituent elements of the latter are composed of physical characteristics in space, while the former comprises mobile elements. The economic and the shipping systems together generate pressure on the port system in the form of ever-evolving specific requirements with respect to infrastructure, superstructure, equipment, efficiency and organisation. This prompts a process of time-lagged reaction within the port system to satisfy this changing demand and it is this reactive progression that actually constitutes the port development process, determined by and reflected in its physical (infrastructure and superstructure), economic, social/environmental and institutional arrangements.

Changes in the port system occur in an almost completely discrete manner, since variations in port infrastructure and superstructure, as well as organisational changes, do not occur in a continuous fashion; investment in the port sector is often characterised as 'lumpy' 
(Sánchez and Wilmsmeier, 2010). Moreover, port development is very often dependent upon and determined by the degree to which a specific port in question is embedded within local and regional institutional considerations and, therefore, beyond the direct sphere of influence of the port system itself. This is critically important not only to the port but also to the economy it serves as it is this that ultimately defines the degree of connectivity enjoyed by the economic system that prevails within a port's hinterland.

Due to the fact that the port system development cycle advances in a discrete manner, its adjustment to the continuous evolution of freight transport demand will inevitably lead to alternating situations of either infrastructural insufficiency or scarcity of supply on the one hand (i.e. excess demand), or to a surfeit of port infrastructure (i.e. surplus supply). In addition to such natural cycles, there is the long-term lifecycle of the port, through development, introduction, growth, maturity and decline (Cullinane and Wilmsmeier, 2011). It has been suggested that early spatial port development models such as Bird (1963) or even the more recent UNCTAD generational model (UNCTAD, 1992) are unable to capture the complexity of port infrastructure, operations and services (Bichou and Gray, 2005). Beresford et al. (2004) developed the WORKPORT model as a response to the need to conceptualise the complexity of this operational environment.

Institutional approaches to port development have argued that the port authority has constraints on its ability to act, stemming from its specific nature. The key distinction is that port development is path dependent, heavily constrained by past actions and institutional design, but also contingent, in relation to private investment and public planning (Notteboom, 2009). Ng and Pallis (2010) showed how port governance is largely determined by local/regional institutional characteristics, despite attempts to implement generic governance solutions. Notteboom et al. (2012) applied the concept of institutional plasticity (Strambach, 2010) to port development, arguing that, while port development is path dependent, a port authority can achieve governance reform by a process of adding layers to existing arrangements. In this way, the port authority does not break from the existing path of development, but develops new capabilities and activities via a process of "institutional stretching". An example is given of port authorities investing in load centres in the hinterland, beyond their traditional jurisdiction, and the particular importance of informal networking is noted (see also Monios and Wilmsmeier, 2012). Jacobs and Notteboom (2011) asserted the need for an evolutionary perspective, drawing upon the economic geography literature to define the movement from critical moments to critical junctures, concluding that port authorities have windows of opportunity in which collective action is possible. The authors 
concluded that "the question of to what extent critical moments require institutional adaptations in order to materialise into critical junctures needs further thought" (p.1690).

In this paper it is argued that, in order to make use of previous work, a more sophisticated institutional appreciation of the port is required, as the entity normally considered a unified port is not only created by numerous actors but is endlessly being recreated with each new relationship or network in which the port is embedded. Thus the port's connectivity is always changing and being recreated. Marx believed that the capitalist system carries "within it the seeds of its own destruction" (Marx and Engels, 1850; unpaginated). Perhaps the same logic could be applied to ports as they move through their life cycle, as the symptoms of success (concentration of container flows at a single port) are themselves the cause of congestion, stagnation and decline, if not addressed. The aim of this paper is to understand this process in a more active and flexible manner, in particular the role of secondary ports in managing the transition from stage three to stage four of Wilmsmeier and Notteboom's (2011) four-stage model.

Sánchez and Wilmsmeier (2010) identified the port system as an "autopoietic" system (cf. Maturana and Varela, 1980), meaning that it changes its state with each new input (Schober, 1991), such as time-lagged investments and strategy replication, with the importance of the first mover advantage meaning that a delayed action may no longer be suitable to the new state of the system. Transport systems exhibit a self-organising structure; however, transport autopoiesis is likely to have an especially high inertia when it comes to changing system variables, due to its "lumpy" or time-lagged investments. In developing countries, autopoiesis may be particularly challenged because of their less flexible and reactive institutions. The autopoietic nature of port system evolution is revealed in how the changing of each input changes the state of the system and can render a once-attractive strategy inadvisable if performed too late, once the system has already changed its state. This recursive relationship lies at the heart of the interlinked factors influencing port system evolution.

This paper describes the changes in the evolution of the LAC port system and discusses the drivers of these changes as ports are situated in the interplay between supply (liner shipping services as well as port capacity) and demand (container traffic). While this discussion cannot be conclusive, the aim is to place arguments for a more systemic view of port development (a discussion that usually only focuses on main ports) and to identify arguments that support secondary and emerging ports in their striving to develop their facilities and strategies through appropriate institutional structures. 
The goal of this paper to systematise them will be aided by applying recent theoretical approaches (particularly Jacobs and Notteboom, 2011) to an analysis of the transition of the LAC port system from phase three to phase four. From this theoretical perspective, the paper aims to understand the evolution of maritime networks and the autopoietic nature of port development as secondary ports seek to reposition themselves within emerging feeder markets through a variety of proactive and reactive strategies that involve different actors within a complex institutional environment. The analysis will chart the progress of the LAC system through these phases and look for the critical moments, according to the rationale that such critical moments are likely to be the same in other port systems, hence these findings will be transferable to other contexts.

\section{The Latin American \& Caribbean port system}

\subsection{Overview}

The system can be categorised first by territory and second by coastline: Central America and Mexico (split by east and west coast), South America (split by east, west and north coast), and the Caribbean. Figure 1 shows all LAC ports with 2012 throughput over 100,000 TEU. The analysis in the paper will be structured according to coastline, therefore three subsystems are defined for the purposes of analysis: the Pacific (WCCA, WCM and WCSA), the Atlantic (ECSA) and the Caribbean (Caribbean, ECCA, ECM and NCSA). 


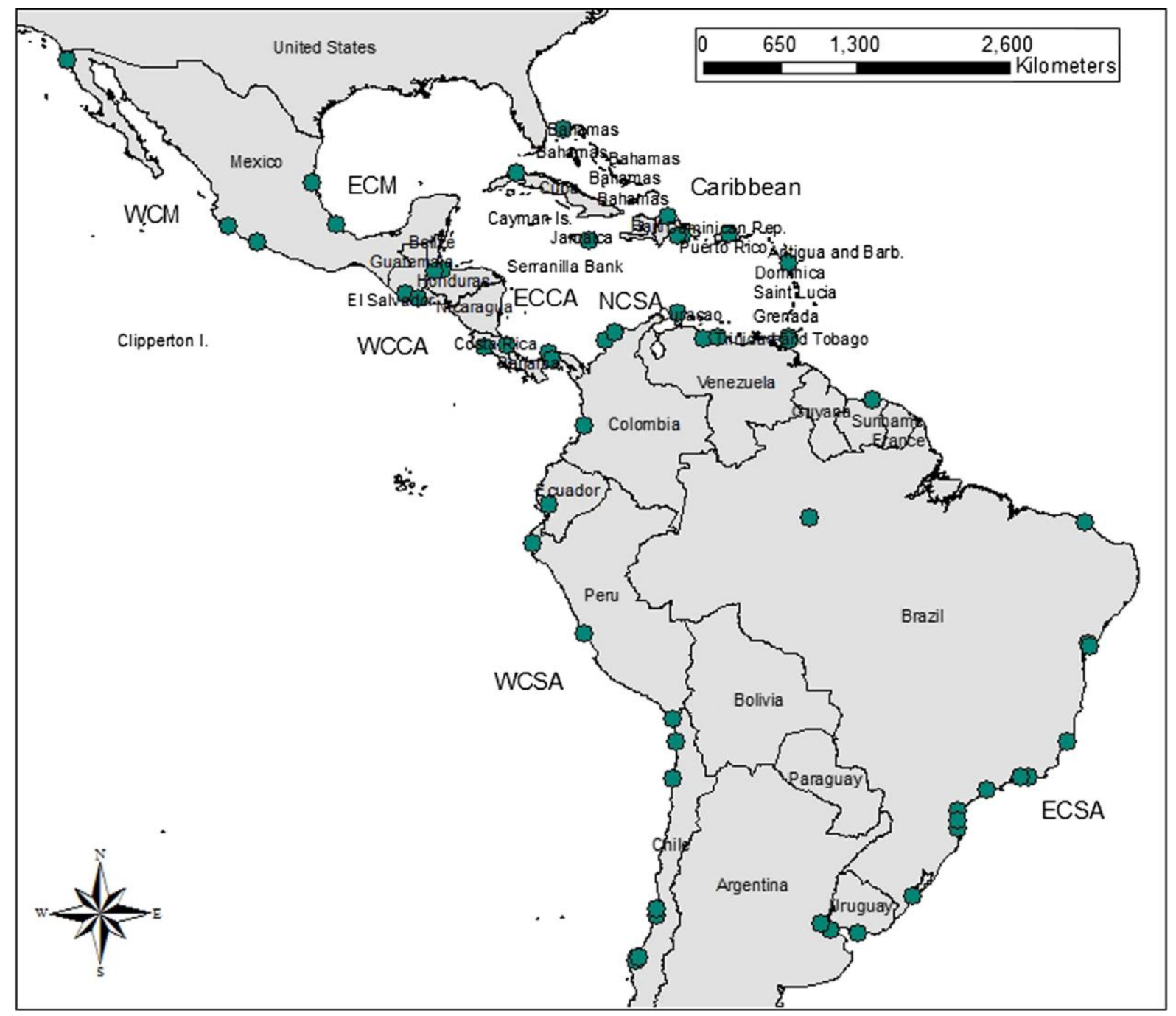

Figure 1: Map showing the main sub-regions within the Latin America and the Caribbean port system (TEU)

Source: authors

(original map will be provided at the publishing stage for higher resolution)

Container throughput in the Latin American and Caribbean port system grew from 12.6 million TEU (twenty-foot equivalent units) in 1997 to 45.6 million TEU in 2012. Throughput in 2012 was equivalent to 7.2 per cent of all global port movements.

Figure 1 reveals the main areas of concentration, but does not show the changes over time. While all sub-regions have grown steadily in absolute terms, their relative share of the LAC market has evolved over time. Figure 2 presents trends in market share across the LAC container market. 


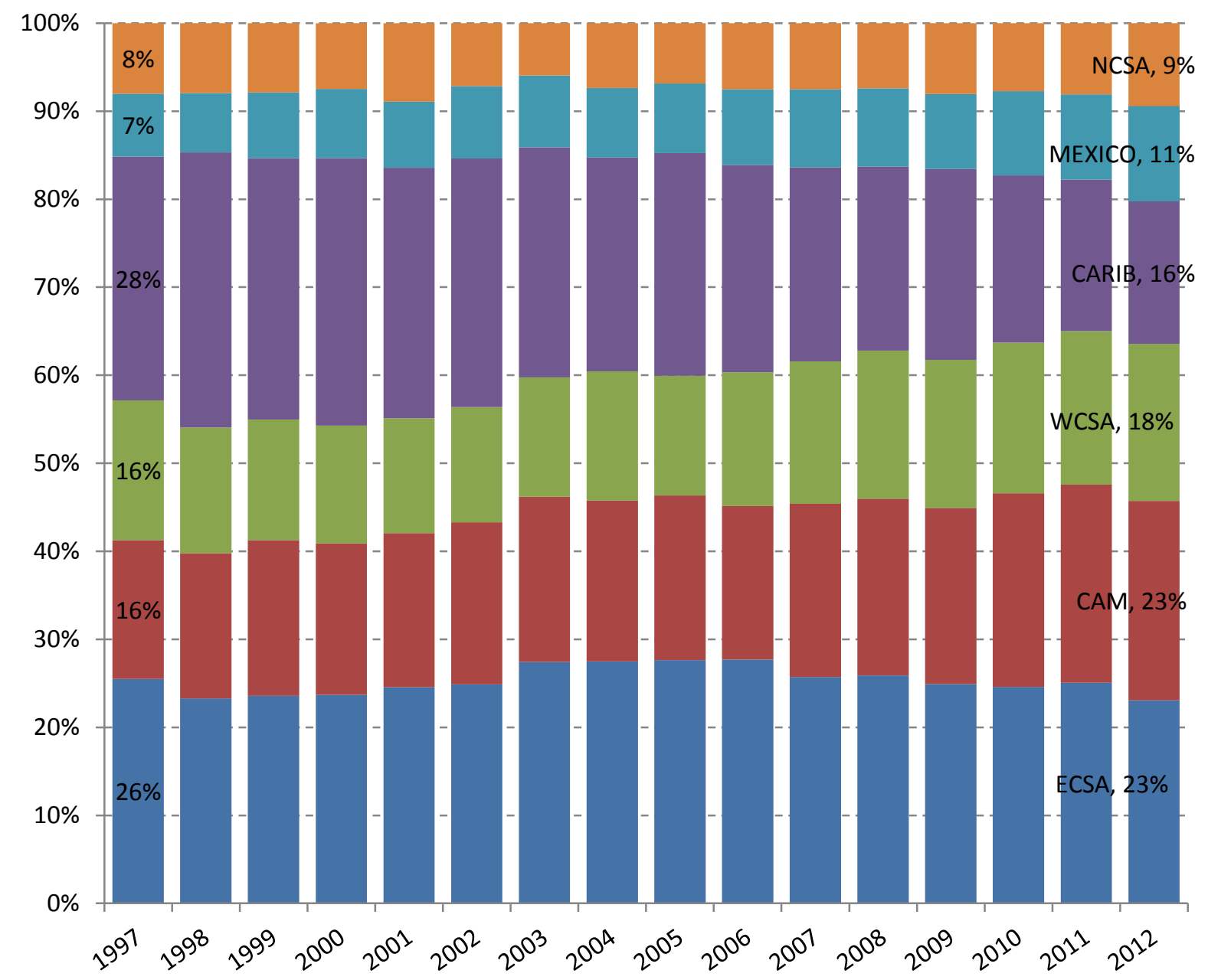

Figure 2: Sub-region's shares in container throughput in LAC, 1997 - 2012 Source authors

Central America (mostly Panama) has recorded the most impressive growth figures over the last 15 years. As port activity growth in Panama is particularly related to transhipment traffic, it might be argued that this is a first indicator of the changes in the port system towards the third phase hub-and-spoke structure as indicated by Wilmsmeier and Notteboom (2011), thus leading to a concentration in the port system towards transhipment hubs, a development that is driven by liner shipping strategies rather than economic development. The Caribbean remains a key market for transhipment; however, it has been losing market participation over recent years, indicating a shift from the traditional transhipment hubs (e.g. Kingston, Jamaica and Freeport, Bahamas) towards Panama and Cartagena, Colombia. A further development is an activity shift in Central America and Mexico from the east to the west coast (Figure 3). 


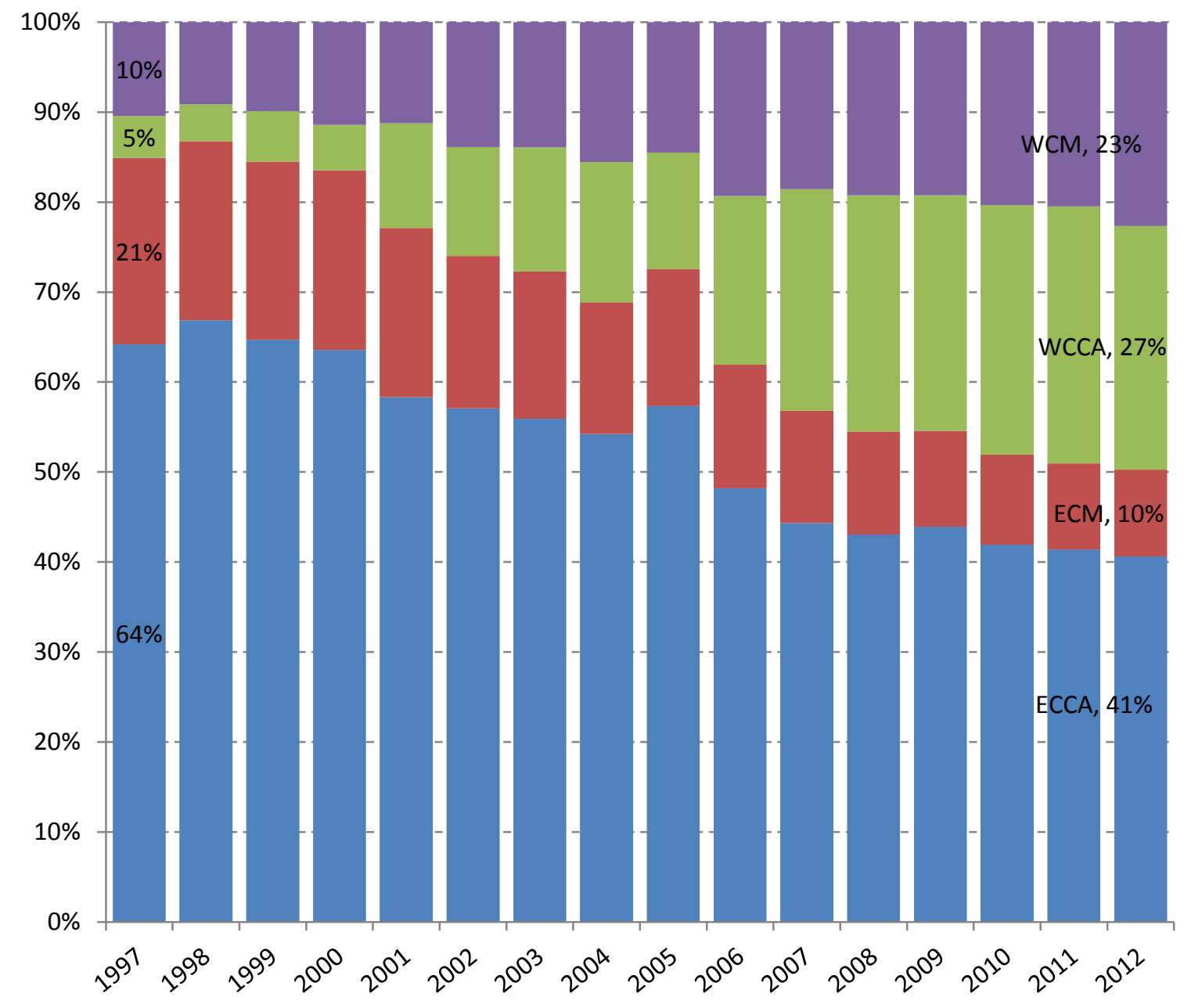

Figure 3: Market share east and west coast Central America and Mexico 1997-2012 Source: authors

The share of container activities has transformed from an 85:15 split between east and west coasts to a 51:49 relation in a market that in 2012 was almost five times bigger than 1997 . This shift can be related to the emergence of Asian countries as the primary trading partners of this region. In contrast, the three coasts of South America have remained in balance, maintaining throughput the time period a proportion of 50:35:15 between east, west and north coasts, respectively.

Analysing port activity by country reveals that in 2012 almost one-fifth of all containers in LAC were moved in Brazil (17.8 per cent), followed by Panama (14.8 per cent), Mexico (10.5 per cent), Chile (7.8 per cent) and Colombia (7.3 per cent). However, the port throughput at regional and country level is only a very crude reference of the current state of the port system. In order to understand the evolution of a port system it is necessary to take a 
spatio-temporal perspective, investigating disaggregated figures at sub-regional and coastal range level over an extended time period.

Figure 4 maps the changes in throughput at LAC ports between 1997 and 2012. 

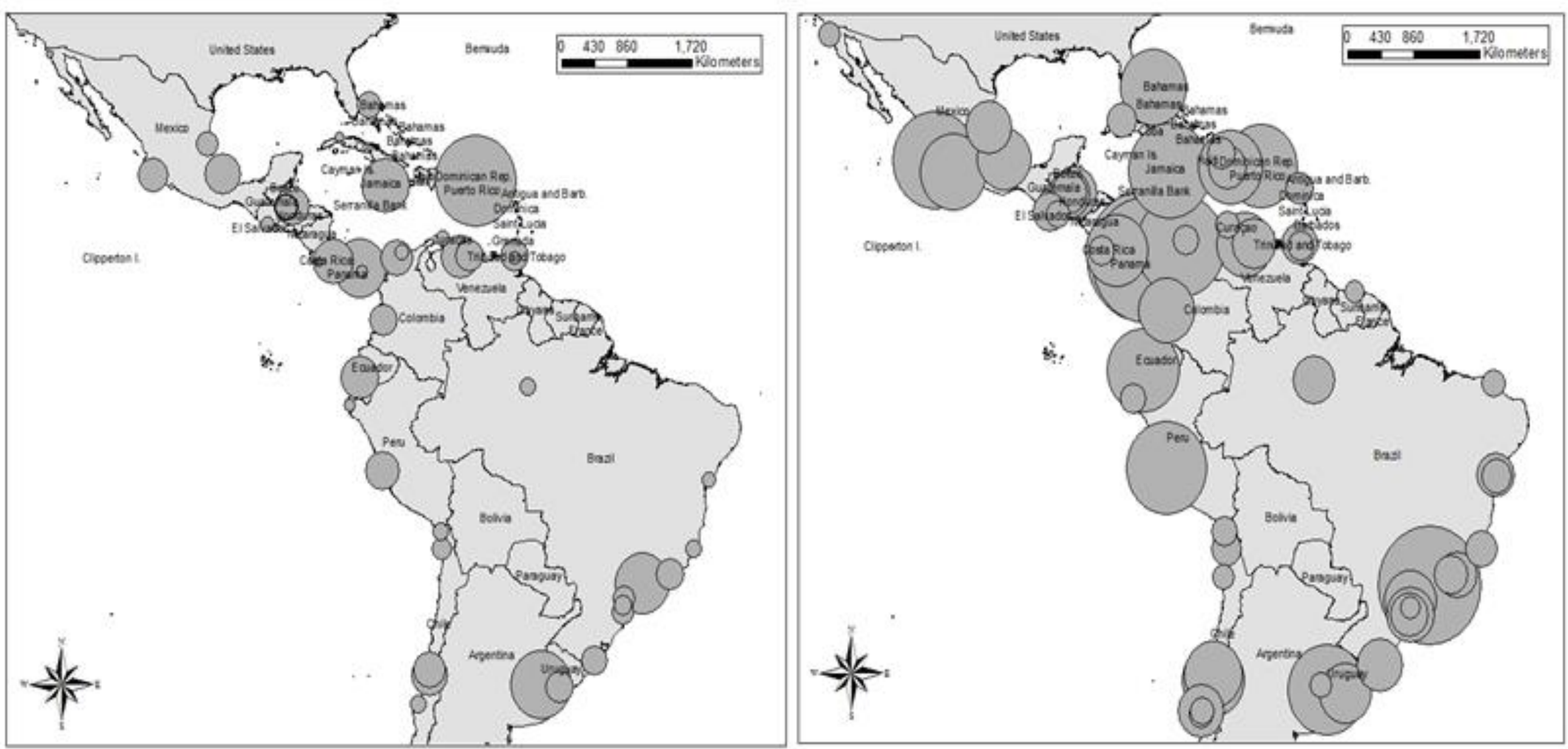

Figure 4. Map of LAC throughput 1997 and 2012 (TEU) Source: authors

(original map will be provided at the publishing stage for higher resolution) 
The map shows the large increases in throughput across all port ranges in the LAC port system. A second result is that, alongside the expected growth of the traditional gateway ports, numerous new port locations appeared over the last decade showing the geographical dispersion of container activity along the different coasts. Furthermore, the maps clearly depict the concentration of container activity in the Caribbean basin (Caribbean, ECCA, ECM and NCSA.

Table 2 in the appendix presents descriptive statistics showing total throughput, number of ports moving more than 100,000 TEU, the Gini coefficient ${ }^{2}$ and the $\mathrm{HHI}^{3}$ in 1997, 2005 and 2012 at the coastal ranges under analysis in this paper. Total growth across the period under discussion is also presented. The statistics show in numerical form what will become clear in the detailed country analysis to follow, although, as discussed by Notteboom (1997, 2006), care must be taken interpreting such broad brush indices; for example, the Gini coefficient is a measure of equality, hence 10 ports in a country with 10 per cent traffic each would give the same index as two ports with 50 per cent each. More nuanced interpretation of the data in Table 2 can be obtained both by viewing the maps (Figure 4) and via a graphical representation of all ports exceeding 100,000 TEU throughput in the LAC coastal ranges (Figure 5).

\footnotetext{
${ }^{2}$ The Gini coefficient ranges from 0 (equality between ports) to 1 (total concentration in one port).

${ }^{3}$ The $\mathrm{HHI}$ ranges from $1 / n$ (equality between ports) to 1 (total concentration in one port), where $n$ is the number of ports. As the minimum $\mathrm{HHI}$ changes according to the number of ports, it has been supplied in the table.
} 


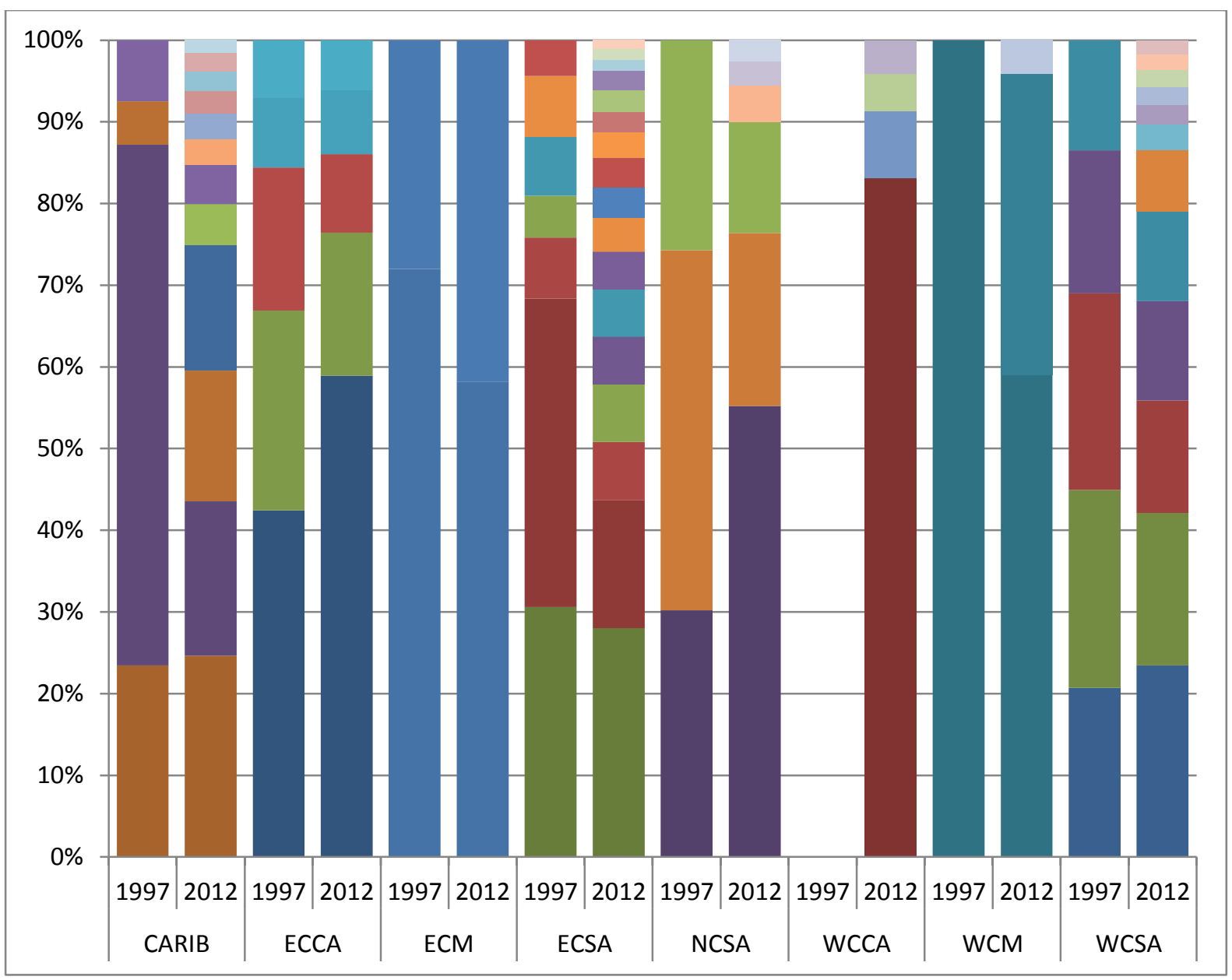

Figure 5. Market shares of ports exceeding 100,000 TEU at the LAC coastal ranges 1997, 2012

Source: authors

Figure 5 shows that the Caribbean is much less concentrated in 2012 due to the loss of dominance from San Juan and the emergence of new ports. The concentration indices have gone down but perhaps not by as much as expected, thus the significance of the change is hidden by the summary indices. ECCA shows an increase in concentration due to the rise of Colón, also reflected by a slight rise in the indices. ECM is slightly less concentrated because Veracruz has lost some share to Altamira. This is reflected by a small drop in the indices. For ECSA, the dominance of Santos has been slightly eroded, while the representation of smaller ports has changed, taking significant share from Buenos Aires. Therefore the indices are relatively unchanged, which does not reveal the dynamics of new developments in this range. The NCSA in the figure shows a clear increase in concentration due to the rise of Cartagena and this is reflected in a rise in the indices. The figure shows that there were no ports in the WCCA exceeding 100,000 TEU in 1997, but this range is now clearly quite concentrated due 
to the dramatic rise of Balboa and the indices over time reflect this. WCM is clearly less concentrated due to the decrease in the market share of Manzanillo and the rise of Lazaro Cárdenas. The indices are little help here as there was only one port above 100,000 TEU in 1997. WCSA is difficult to interpret from the graph, as there has been some increase in share for the dominant port of Callao, and among the smaller ports there have been both winners and losers. The indices are not particularly revealing here, showing a slight increase in concentration over time, likely due primarily to the increase at Callao.

Mapping throughput changes and calculating concentration indices across the LAC port system has revealed significant decentralisation through the emergence of secondary ports as well as some movement from area to area, such as coast to coast in Central America and Mexico, given the changing geography of trade and the emergence of Asian countries as the main trade partners. Both increased and decreased concentration can be observed at different coastal ranges, as they are currently each at different stages of their lifecycle. Most ranges demonstrate the expected pattern of an early rise of one or two dominant ports, followed by the rise of secondary ports which leads to deconcentration. The exceptions are ECCA, NCSA and WCCA. NCSA and WCCA are at the earlier stage of development towards an initial concentration, still witnessing the dramatic rise of a single dominant port, whereas ECCA is the one coastal range not following the expected pattern, as Colón has been able to maintain its dominance. This is due, however, not to changes in its own coastal range but primarily to taking transhipment traffic from Caribbean ports (see section 5.4).

Yet, why new ports have emerged in specific locations cannot be deduced from such simple approaches, especially whether they will all be successful enough to initiate or continue the expected process of deconcentration. First, close analysis of container flows and second, appreciation of the institutional context of the shipping market and port devolution is required. These maps and figures will be explored in detail in the relevant sections below.

\subsection{The Pacific: WCCA, WCM and WCSA}

The maps and broad analysis in section 5.1 identified a significant rise in throughput and the emergence of new ports in WCCA, WCM and WCSA. This section will analyse these trends in more detail. Figure 6 identifies the market share of port throughput on the west coast of Latin America. 


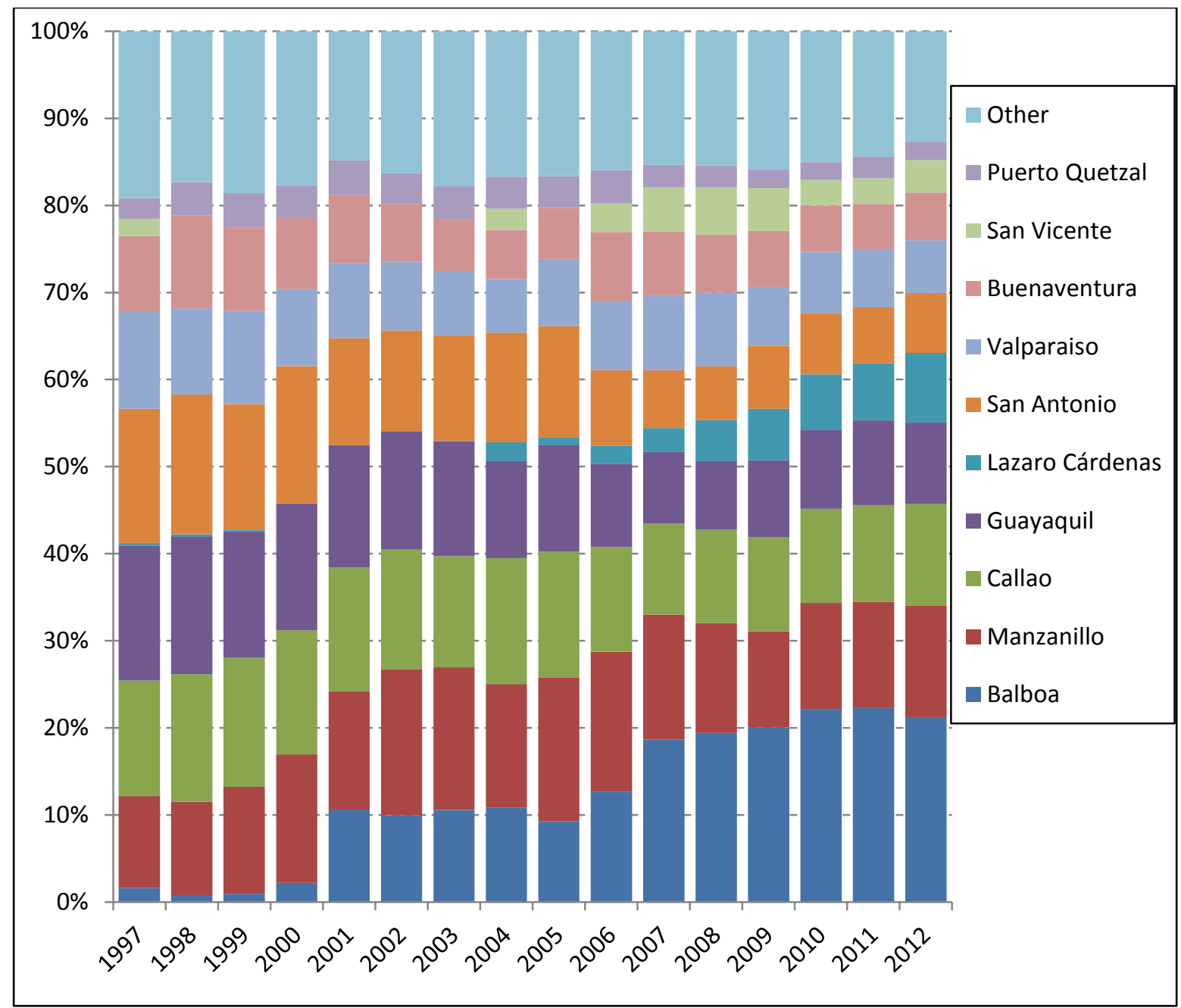

Figure 6. Port throughput shares WCCA, WCM and WCSA, 1997-2012 Source: authors

The figure shows that the transhipment port of Balboa, Panama has been by far the biggest winner on the west coast, as well as the emergence of two new ports Lazaro Cárdenas, Mexico and San Vicente, Chile. Manzanillo, Mexico and Callao, Peru have retained a stable share, while the other ports have all lost out.

The emergence of secondary ports is particularly notable in the case of Chile, which has led to a greater geographical spread of ports towards the south of the country (Figure 7). 


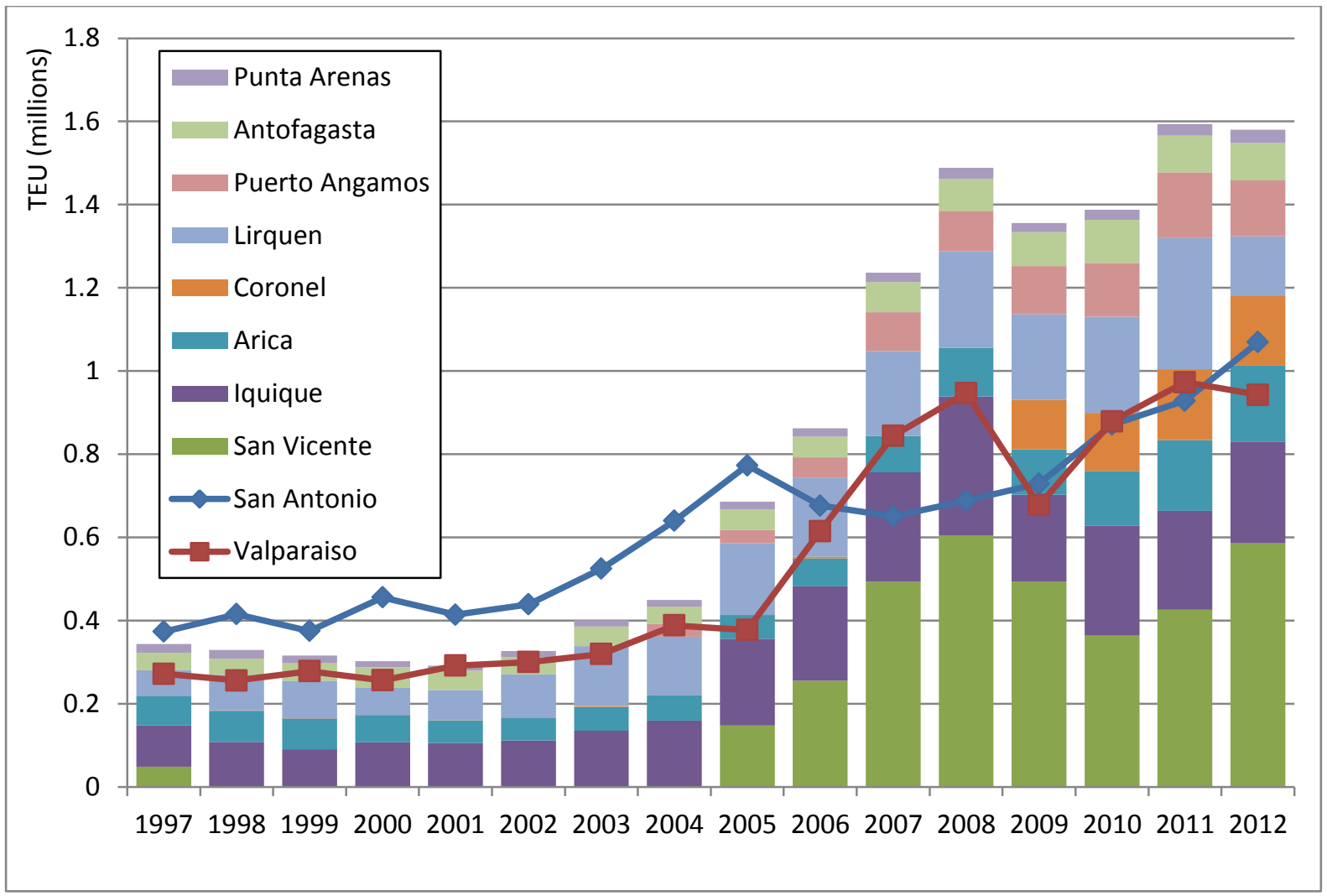

Figure 7: Container throughput in top ten ports in Chile, 1997 - 2012

Note: Valparaiso and San Antonio are shown separately in order to see the smaller ports more clearly

Source authors

The appearance of San Vicente (SVTI) as a new player in 2005 and the growth of the colocated Lírquen appear to support the emerging relevance of secondary ports in the region and a related transformation of the port system. The analysis also reveals that the two traditional main ports effectively lost over seven per cent market share between 2005 and 2012. However, the pure numerical analysis by port does not reveal the systemic relationships in the port system created by the privatisation efforts over the last two decades and the internationalisation of container port operations (see section 6). In the case of Chile this is particularly interesting as the operator of San Antonio is the same as in San Vicente. Thus, while the individual port San Antonio was not able to increase its market share of the port system (although it did grow in absolute terms), the private operator's share in port activity grew strongly when one considers the ports of San Antonio, San Vicente and the other Chilean ports operated by the same company. 


\subsection{The Atlantic: ECSA}

The maps and broad analysis in section 5.1 identified a significant rise in throughput and the emergence of new ports across the ECSA. This section will analyse these trends in more detail. Indeed, a somewhat similar picture emerges to the west coast analysis in the preceding section. Figure 8 shows shares in container throughput at the top ten ECSA ports.

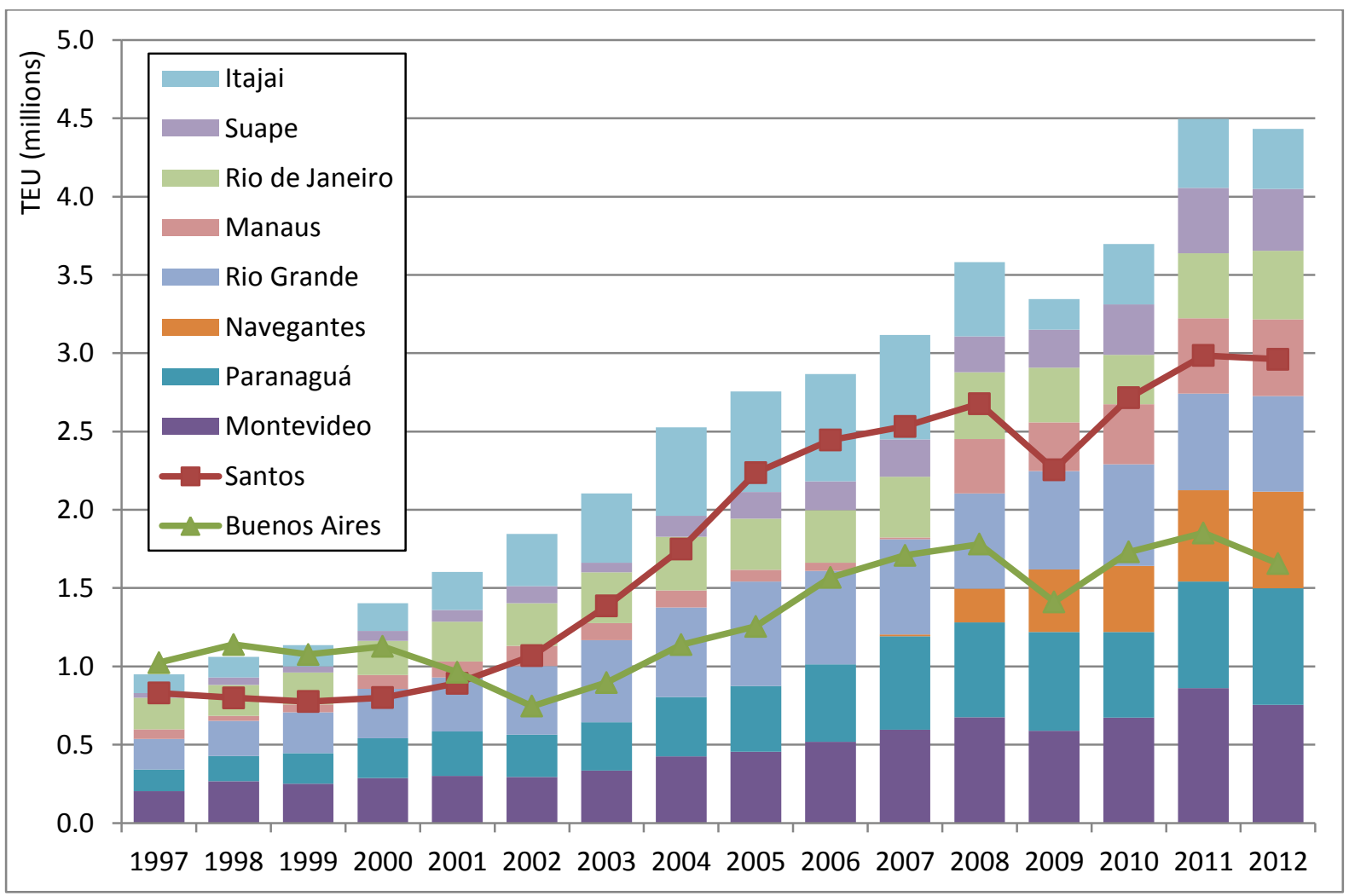

Figure 8: Shares in container throughput ECSA, 1997 - 2012

Note: Santos and Buenos Aires are shown separately in order to see the smaller ports more clearly

Source authors

Between 1997 and 2012 overall container throughput in ECSA ports more than tripled, from 3.2 to over 10.9 million TEU in 2012. This was accompanied by a significant shift in the market participation of the ECSA countries. Brazil's share of container movements expanded from 60 per cent to 75 per cent while Argentina lost 45 percent of its market share and in 2012 generated only 18 per cent of all container traffic in the ECSA. The figure shows a clear contrast between the growth of the coast's two major ports of Santos (Brazil) and Buenos Aires (Argentina). The emergence of secondary ports such as Navegantes is particularly striking, opening in 2007 and reaching 618,434 TEU by 2012. 
This shift originates principally from the expansion of Brazil's economy, paired with its population size. By way of example, Brazil today is one of the world's largest exporters of chicken and beef, a trade that has only recently developed as a response to the growing demand in the emerging Asian economies. Uruguay, the smallest economy on the ECSA, was able to grow its market share to almost 8 per cent. This achievement is driven not solely by the economic development of the country, but also by its strategy to act as transhipment hub and gateway for Paraguayan as well as southern Argentinean cargoes (see also Wilmsmeier, Martinez-Zarzoso and Fiess, 2010).

In addition to the shift in market participation at country level, the traditional concentration within each of the national container port systems is being diluted by the entrance and development of new players. In the case of Argentina the deconcentration process is still in its infancy, but it is noteworthy that the container terminals in Buenos Aires have lost about 6 per cent of national market share over the last 7 years, showing the fast expansion of new container ports (e.g. Zarate) in the country (for earlier figures and discussion of competition in the River Plate region see Sánchez and Wilmsmeier, 2006).

Traditionally, Santos has been the principal container port in Brazil and 36 per cent of Brazil's container throughput was handled in the terminals of Santos in 2012. Nevertheless, its market decreased in comparison to 1997, when the port was responsible for over 43 per cent of Brazil's container movements. Rio de Janeiro as the second biggest container port in Brazil in 1997 lost 50 per cent of its market participation over the last 15 years. A number of secondary ports and greenfield projects emerged that not only led to a geographic spread of container activity but also initiated a deconcentration process. Rio Grande held an important market participation of 10 per cent in 1997 and was expected to evolve as a competitor to Montevideo and Buenos Aires in the south of Brazil as its infrastructural conditions and draft of $15 \mathrm{~m}$ favoured the handling of post-panamax vessels. The port expanded and increased its market share to over 13 per cent in 2003, benefitting from the repercussions of the economic crisis in the port of Buenos Aires (see Sánchez and Wilmsmeier, 2008). However, since then its share in Brazilian container throughput has decreased to only 5.3 per cent in 2012. Its continued growth was not, therefore, sufficient to keep up with the speed of expansion of overall national container activity. Looking at other ports, the co-located ports of Itajai and Navegantes taken together doubled their market share to 12.2 per cent in 2012, Manaus also doubled its share to 6 per cent, while Suape tripled its participation to 4.8 per cent in 2012 . 


\subsection{The Caribbean: Caribbean, ECCA, ECM and NCSA}

The maps and broad analysis in section 5.1 identified a significant rise in throughput and the emergence of new ports across the sub-region comprised of the Caribbean, ECCA, ECM and NCSA. This section will analyse these trends in more detail. Port throughput in this subregion grew from 7.0 million TEU in 1997 to 19.8 million TEU in 2012. Figure 9 shows the split between sub-regions in the Caribbean, east coast Mexico and Central America and North coast South America.

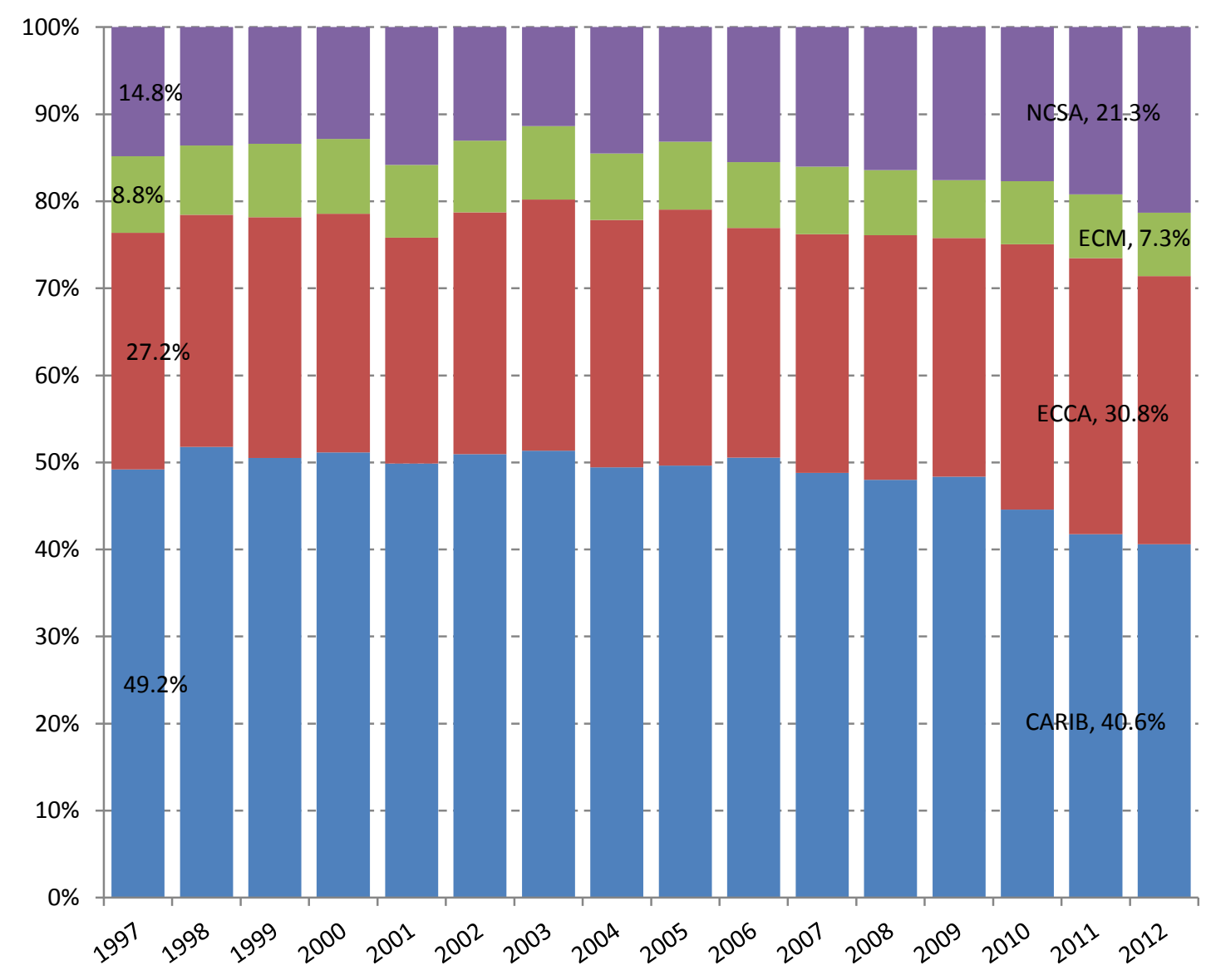

Figure 9. Market share per sub-region, Caribbean, ECCA, ECM, NCSA 1997-2012 Source: authors

The figure reveals that the market is relatively stable, with a slight increase for ECCA and NCSA at the expense of the Caribbean. In order to understand this point further, the different kinds of ports in this region need to be considered. The ports in this port system can be categorised as follows: pure transhipment hubs (minimum of 70 per cent transhipment cargo), hybrid ports (between 30 and 70 per cent transhipment cargo), gateway ports (less than 30 per cent transhipment cargo) and local and inter-islands transhipment ports. Figure 10 charts the 
change in time of container traffic at transhipment and hybrid ports and reveals the success of hybrid ports in terms of gains in market share (i.e. Cartagena, Colombia).

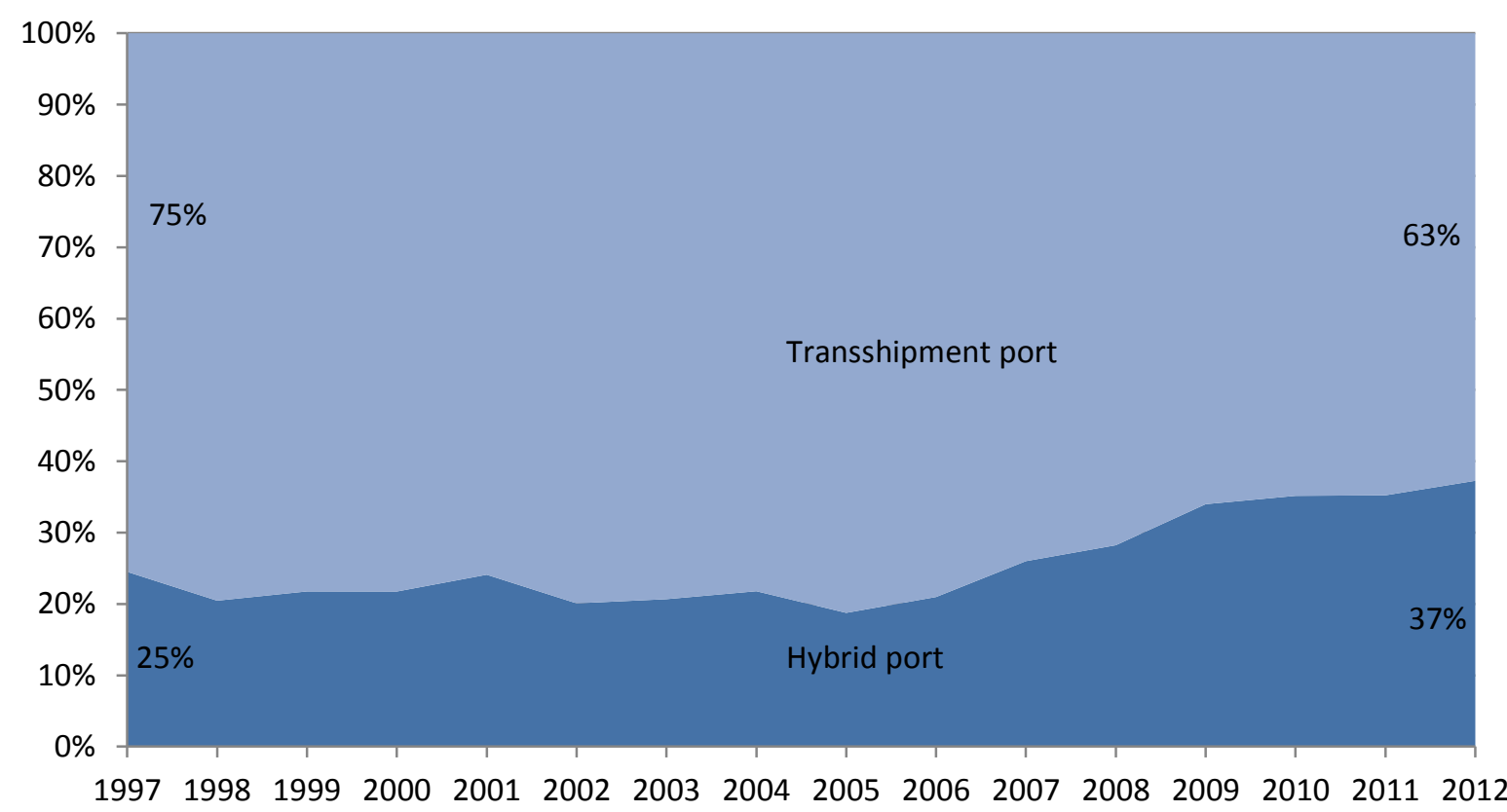

Figure 10. Shares in container traffic by port type in Caribbean/ECCA/ECM/NCSA, 1997 2012

Source: authors

In order to look specifically at transhipment traffic, Figure 11 maps the location of transhipment traffic relative to gateway traffic in this sub system in 2011 (based on percentages). 


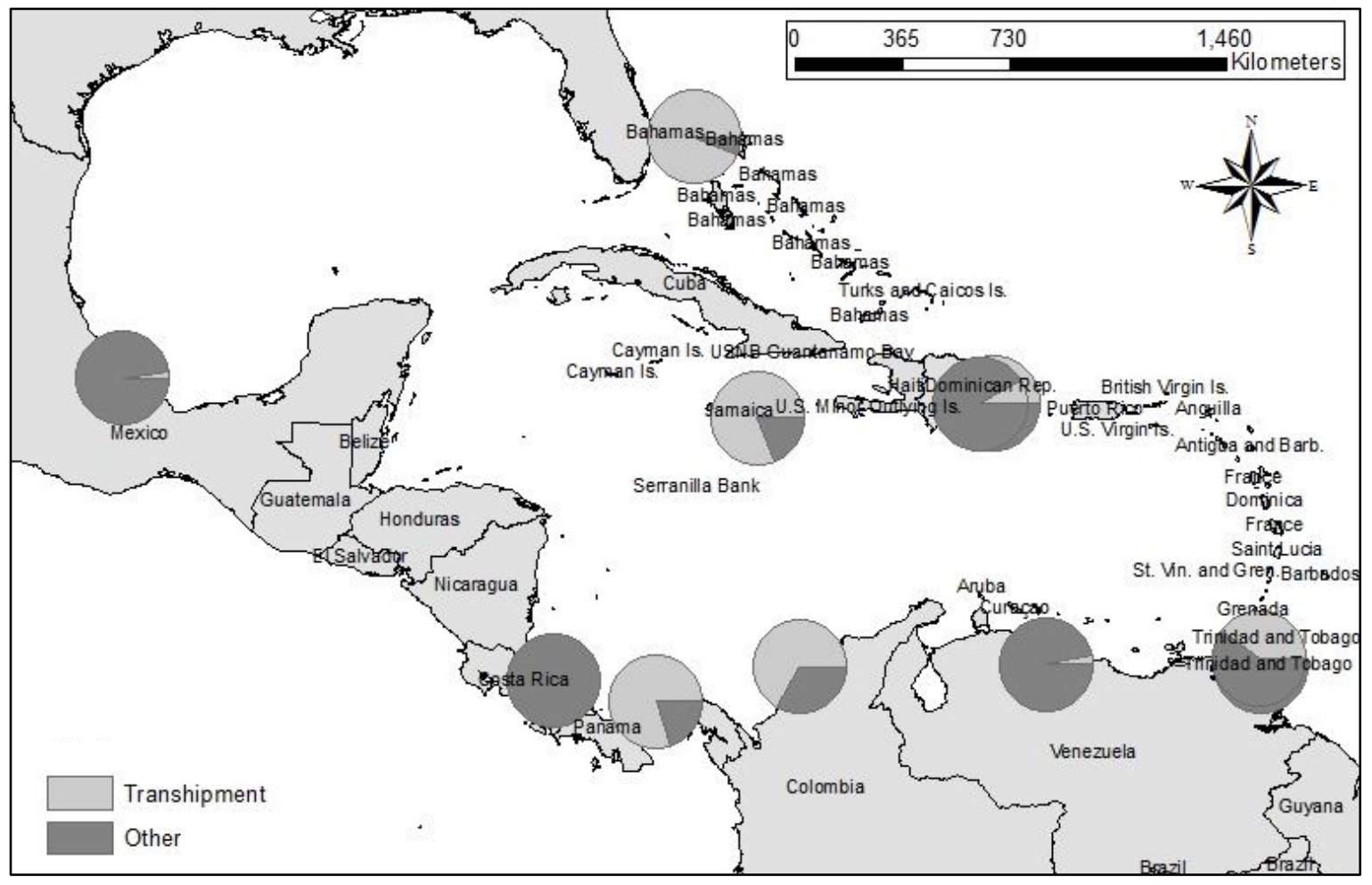

Figure 11. Map showing percentage of transshipment traffic at ports in the Caribbean/ECCA/ECM/NCSA 2011

Source: authors, based on Sánchez (2012)

The map identifies the key transhipment locations serving the Caribbean basin. Figure 12 shows throughput growth over time for those ports defined as primarily transhipment ports. 


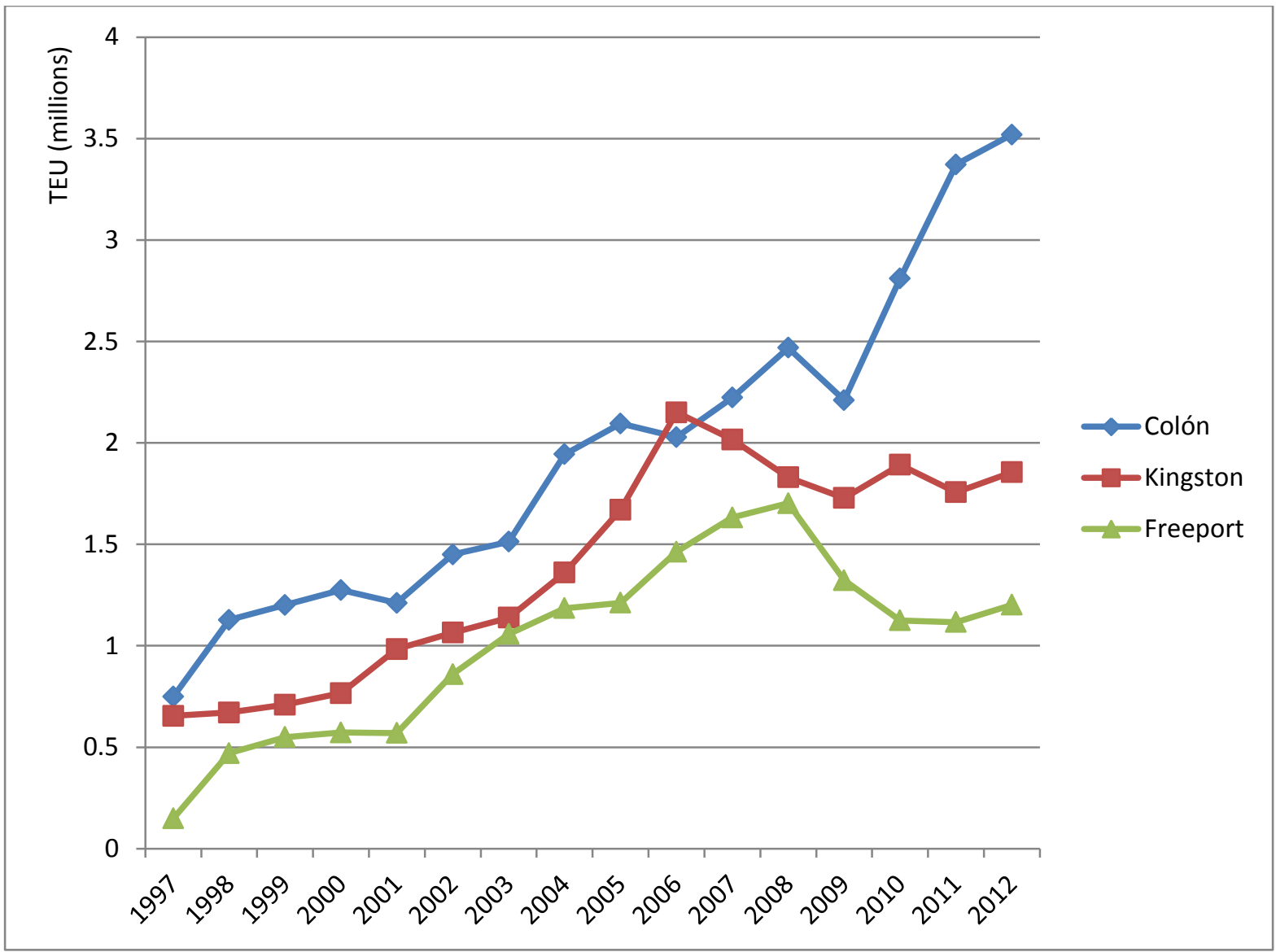

Figure 12. Evolution of container throughput at transhipment ports in the Caribbean basin $1997-2012$

Source: authors

Colón, Panama is the clear winner. As well as recording significant growth in absolute terms, it has retained its approximately 50 per cent market share. Freeport has taken some market share from Kingston, but importantly, Colón has been able to maintain its upward trend of container throughput while both other transhipment ports have dipped in the last few years.

The share of local ports declined, while the share of gateway traffic has remained stable between 1997 and 2012. Cartagena, Colombia was the most successful hybrid port by increasing its market share from 4 to 11 per cent in the same period, while other hybrid ports Port of Spain and Point Lisas were not able to increase their market share, despite overall traffic growth. Other points of interest are the emergence of new ports such as Caucedo, Dominican Republic, opening in 2005 and reaching 1.2 million TEU by 2012.

Cartagena's transhipment share in total container movements increased significantly since 2005 when Hamburg Süd decided to make the port its strategic transhipment hub for Latin America and the Caribbean connecting to seven of the carrier's services between North and 
South America, the Caribbean, the Mediterranean and North Europe. Hamburg Süd's transhipment volume through Cartagena has increased fivefold between 2006 and 2012 (Port Strategy, 2012). A particular case in this category is Caucedo, Dominican Republic. The port appeared in 2003 based on a greenfield development and operated by the global terminal operator DP World with the aim to become a new transhipment port in the region. Since then the port has evolved to a hybrid port by capturing significant amounts of the increase in local destination cargo and at the same time pursuing the goal of attracting more transhipment cargo, which reached a share of above 50 per cent of all container movements in 2011 . The success of hybrid ports suggest the growth of secondary ports as second-tier regional hubs, similar to the findings in the Chinese port system by Wang and $\mathrm{Ng}$ (2011). Such ports have managed to insert themselves in between global and local flows, providing transhipment to intermediate services as well as serving local and regional gateway traffic. However, analysis of shipping line services is required to explore this finding in more detail, which lies beyond the scope of this paper.

Gateway traffic is more complex, as due to the difficult geography of the regions, many gateway ports are not competing for an overlapping hinterland. Therefore, traffic counts are related more directly to the increase of global trade rather than changes in the port system. Most gateway ports experienced a similarly steady increase in total throughput across the time period.

\section{Port devolution and development in the LAC port system}

Beyond the changes in throughput volumes, the appearance and evolution of port devolution processes in the region since the beginning of the 1990s have marked critical moments for those countries and ports involved. This development is closely linked to the influx of international port terminal operators in the region (see also Sánchez and Wilmsmeier, 2006). In 2006, 33 container terminals were being operated by international terminal operators in 12 countries of the region. This number increased to 66 by the beginning of 2012 (Figure 13). 


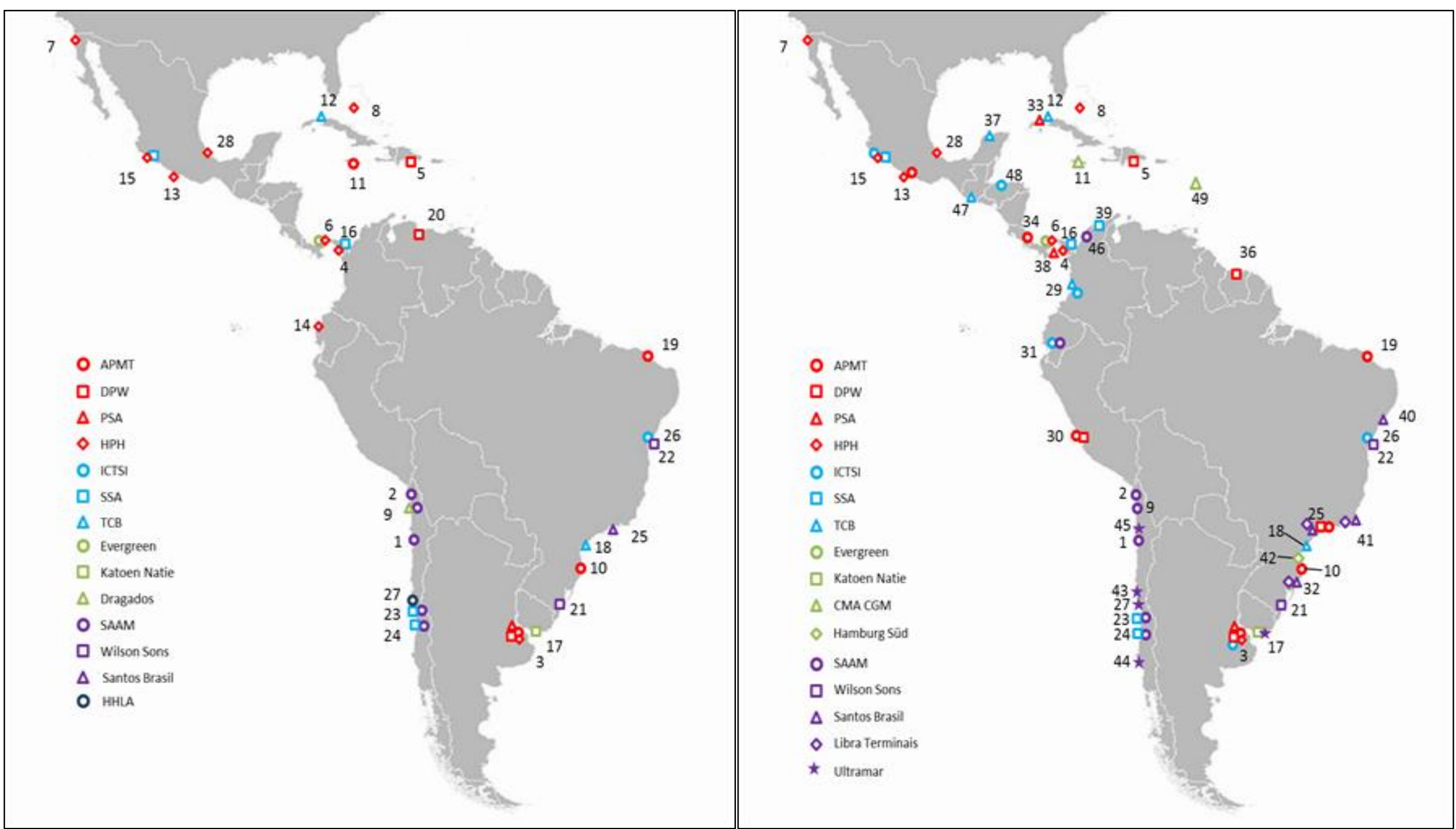

Figure 13. Map showing influx of global terminal operators in LAC ports

Source: authors, based on Sánchez (2014)

(original map will be provided at the publishing stage for higher resolution)

Note: 1 Antofagasta, 2 Arica, 3 Buenos Aires, 4 Balboa, 5 Caucedo, 6 Colon/Cristobal, 7 Ensenada, 8 Freeport, 9 Iquique, 10 Itajaí, 11 Kingston, 12 La Habana, 13 Lázaro Cardenas, 14 Manzanillo (ME), 15 Manzanillo (TI), 17 Montevideo, 18 Paranagua, 19 Pecem , 21 Rio Grande, 22 Salvador, 23 San Antonio, 24 San Vicente, 25 Santos, 26 Suape, 27 Valparaíso, 28 Veracruz, 29 Buenaventura, 30 Callao, 31 Guayaquil, 32 Imbituba, 33 Mariel, 34 Moin , 36 Paramaribo, 37 Progreso , 38 Rodman, 39 Santa Marta, 40 Vila do Conde , 41 Río de Janeiro, 42 São Francisco do Sul , 43 Coquimbo, 44 Coronel, 45 Mejillones , 46 Cartagena, 47 Quetzal, 48 Puerto Cortés, 49 Fort-de-France. 
While the simple presence of private port operators is not a guarantor of success in port and terminal development, it can be argued that these operators changed the level of competition in the different sub-regions. Until 2006 intra-port competition was restricted to the port of Buenos Aires, the Caribbean coast in Panama and the competition between Valparaiso and San Antonio in Chile as they serve a congruent hinterland. Since then the further influx of international terminal operators has brought a new level of intra-port competition to Callao, Peru (APMT and DPW), Panama's Pacific coast (PSA and HPH), Buenaventura, Colombia (TCB and ICTSI), Lazaro Cárdenas (APMT and HPH), Manzanillo, Mexico (SSA, HPH, ICTSI) and Santos, Brazil (DPW, APMT and Santos Brazil).

It is interesting to observe that each international operator shows specific geographical specialisation strategies. In the first phase, during the influx of international operators, the interest concentrated on the countries' main ports of which many in the 1990s did not have sufficient scale to make operation viable for two competing operators (except Buenos Aires and Panama's Caribbean coast). The continued growth in demand changed this situation and, since 2005, the increase in competition can be observed, as described above. HPH has a clear dominance in the Central American and Mexican market. APMT has been focussing on new terminal developments with a strong interest not only in transhipment cargoes but lately in gateway ports with potential to develop towards hybrid ports. DPW has a more equal presence in each sub-region. These findings underline the advances in the evolution of the port system as asserted by Wilmsmeier and Notteboom (2011) and discussed in section 3.

Given the historic need for infrastructure development in the region, most development took place initially in the main ports. However, in more recent years, secondary ports started to engage in more integrated development strategies that also included the consideration of logistics development connected to the port (e.g. Manaus, Brazil; Puerto Angamos, Chile). The maps above also reveal how the activities of international terminal operators spread from the region's main ports to secondary ports. Examples are Santa Marta Colombia, Coronel, Chile, and a number of Brazilian ports such as Vila do Conde.

A recent study (Wilmsmeier 2013) showed that the changes in ship characteristics on main routes in the regions poses significant challenges to infrastructure development as certain vessels calling at the region already require $15 \mathrm{~m}$ draught in ports, a requirement that only few ports fulfil at this point in time. Due to the continued crisis in the liner shipping sector, vessels are cascading down to secondary LAC routes, creating requirements for new infrastructure not only in the region's main ports but also at the secondary ones. If some ports are not able to handle larger ships due to insufficient berthing or handling capacity, this 
would support the growth of regional second-tier hubs, which can then serve the smaller ports either by smaller feeders or even land transport in some cases (thus raising issues relating to the quality and capacity of hinterland infrastructure links). This situation implies a return to the discussion on the lack of infrastructure and the success of port reform to close the infrastructure gap from the 1990s. Moreover, the situation requires investigation regarding the degree to which the institutional settings in the sub-regions are sufficiently developed to address the current challenges.

\section{Identifying critical moments of institutional transition}

The focus in previous research has been almost exclusively on the development of main container ports, giving only residual attention to secondary port development in the region. Therefore many of the changes described in this paper and the resultant transformations in the different sub-regions have happened almost unnoticed and have consequently not been part of a contextual debate on port system development challenges and opportunities in the LAC port system.

The devolution of port management and operations and, more generally, the deregulation of transport services, have opened new opportunities for development in the region. Port devolution transformed the institutional structure in which actors and their relationships were embedded; this transformation spurred new strategies that required, at least on behalf of the successful ports, an identifiable process of institutional adaptation.

These new developments offer opportunities for policy implementation that reach beyond the physical development of single port infrastructures and traditional operational facilities in main ports. What is required is to address more strategic and integrated possibilities of system development. Success in an increasingly competitive environment can only be achieved if public institutions and private sector actors are able to identify the critical moments and convert these into crucial junctures.

Derived from both the literature on port system evolution (sections 2 and 3) and the preceding analysis, Table 1 depicts the main critical moments that can be identified to have influenced the port system in Latin America and the Caribbean. The table classifies the moments into six categories. 
Table 1: Critical moments in LAC port development between 1997 and 2012

\begin{tabular}{|c|c|}
\hline Influence & Critical moments \\
\hline Economic growth & $\begin{array}{l}\text { - } \text { growth of container volumes } \\
\text { - } \quad \text { changing geography of trade } \\
\text { - change in the structure of cargoes }\end{array}$ \\
\hline Technological change & $\begin{array}{l}\text { - } \quad \text { ship size } \\
\text { - } \quad \text { automation of superstructure } \\
\text { - logistics information systems }\end{array}$ \\
\hline Port devolution & $\begin{array}{l}\text { - } \quad \text { port reform } \\
\text { - influx of international private operators } \\
\text { - intra-terminal competition }\end{array}$ \\
\hline Port function & $\begin{array}{l}\text { - } \text { gateway ports } \\
\text { - hybrid ports } \\
\text { - } \text { transhipment ports }\end{array}$ \\
\hline Shipping line strategy & $\begin{array}{ll}\text { - } & \text { direct services } \\
\text { - } & \text { transhipment strategies } \\
\text { - } & \text { liner-specific transhipment hub }\end{array}$ \\
\hline Port system & $\begin{array}{l}\text { - } \text { one main port } \\
\text { - new terminal development - inter-terminal competition } \\
\text { - diversification - emergence of secondary ports } \\
\text { - geographical shift- emergence of new ports }\end{array}$ \\
\hline
\end{tabular}

Source: authors

Economic growth caused an increase in throughput across all sub-regions within the LAC port system, in line with global growth in container throughput. Technological growth led initially to the expansion of previously dominant ports, usually one in each country (section 5.1). This process was supported by port reform that enabled both operational advances in port operations as well as the introduction of intra-port competition, supported by increases in demand that made such competition economically viable (as discussed in section 6). Port functions then began to change, as dominant gateway ports lost some of their market share to transshipment ports, increasing movements of feeder vessels to secondary ports (discussed in section 5). This is where shipping line strategy comes in, which for space reasons was only touched on as part of this analysis, but is an essential aspect of transitioning through the four stages of the Wilmsmeier and Notteboom (2011) model, and is therefore a topic for further research. The final category in Table 1 is port systems, which was the primary focus of the quantitative data analysis in section 5 of this paper. The focus on the geographical scale of the LAC region precludes detailed analysis of all ports (except where used as examples), 
therefore it is not possible in this analysis to specify which exact critical moments were utilised by individual ports. However, the emergence of new ports, their geographical location and their role within the port system hierarchy have been identified in this paper and some explanations for this development can now be put forward, as it is hypothesized that they will also explain the transition from phase three to four of port development in other global contexts.

The analysis in the maps and charts in section 5 showed that these critical moments did not appear either in sequence or simultaneously but rather in a diversified spatio-temporal manner, suggesting the influence of local and regional institutional specificities. The analysis of concentration and deconcentration at coastal ranges in section 5.1 showed that not all ranges are at the same point in their life cycle. The framework elaborated in Table 1 can therefore be utilised to systematise analysis of different regional contexts and identify the instances of such key influences used by secondary ports to alter the port system.

The data analysis in section 5 showed evidence of decentralisation of container traffic within the LAC port system and deconcentration at most of the individual port ranges (depending on their stage in the lifecycle), with both the maps and the data analysis revealing the challenges posed to traditional gateway ports by emerging secondary ports within each country. These identified shifts have potential benefit for secondary ports identified in this paper, some of which are pursuing significant expansions to take advantage of this expected trend. These ports seek to reposition themselves within an emerging feeder market (section 5.4) that could reduce their peripherality that has been embedded by the traditional LAC port and infrastructure system, thus enabling such secondary ports to compete with the traditional major gateway port in their country.

The use of the first mover advantage for greenport development (for example, in Caucedo) is already showing repercussions in the market participation of ports. The advantages gained by these ports in the battle for position, particularly in the transhipment market, will be difficult to replicate by competitors that have only recently started to develop their strategy in this direction. The autopoietic nature of port system evolution is revealed in how the changing of each input changes the state of the system and can render a onceattractive strategy inadvisable if performed too late, once the system has already changed its state. The paper thus raises questions about port policy and both public and private sector responses to a changing LAC port geography. Global replication of identical strategies will not work unless the correct mix of critical moments are arrayed in a suitable spatio-temporal pattern. Identifying and classifying such an ideal pattern for each development choice is not 
possible from this brief analysis (if indeed an ideal universal pattern exists), yet some insights can be gained from assessing a single port system through this theoretical lens.

When analysing the evolution of a port system and its sub-systems, it is important to be aware not only of path dependence exerted by previously-dominant ports but the contingency of port development upon port devolution, competition and public planning approval. The work in this paper underscores the temporal aspect of path dependence in the recognition that, for overcoming peripheral status, the first mover advantage is of considerable importance. This observation supports the view of Jacobs and Notteboom (2011) that the "window of opportunity" has to be open long enough to achieve the institutional transformation at the critical juncture, otherwise the window closes again.

When fighting for a small regional market, coming in against an incumbent is difficult in a sector with large upfront investment, large sunk costs and a long payback period. However, proactive strategies such as those by Caucedo and Cartagena seem to be challenging traditional path dependence, providing evidence of "the production of locational effects as a result of capital investment in space" (Swyngedouw, 1992; p.424). Fleming and Hayuth (1994) have also noted how the virtues of centrality and intermediacy that create strategic locations can be manufactured. The analysis in this paper shows that the manufacturing of strategic locations, if performed at the right stage of the system, can be successful and may indeed have driven the emergence of secondary ports in the LAC system. This reveals how port systems can move from phase three to four of Wilmsmeier and Notteboom's (2011) port system model, where path dependence is challenged by new developments.

\section{Conclusion}

Geographical analyses of port system evolution have proceeded from traditional spatial models to more recent focuses on port competition and the structure of maritime services. This paper focused on the Wilmsmeier and Notteboom (2011) four phase model, in particular the transition from phase three (mature hub-and-spoke networks, port devolution, penetration of international operators) to phase four (rise of direct services, current hubs undermined and the rise of new secondary hub-and-spoke networks). The many influences on this transition are not yet fully understood. The goal of this paper was, therefore, to perform a detailed analysis of a representative case in order to develop a framework for systematic analysis of this important phase of system evolution. Both quantitative (analysis of time series data on port throughput and location) and qualitative (discussion of institutional adaptation through port devolution and the development of new ports) data were used, within the guiding 
framework of the need to identify critical moments that are the drivers for transition between port system phases.

The quantitative results showed clear evidence at most coastal ranges of initial concentration followed by deconcentration, as per the model, with some exceptions, as explained in section 5.1. The rise of secondary ports and new transshipment structures were also identified. The qualitative analysis supported these findings, showing the devolution of port operations to the private sector and the actions of shipping lines and terminal operators penetrating the market and investing in competitor ports. The institutional framework produced by a synthesis of the literature with the empirical case enabled an identification of the key critical moments influencing the transition from phase three to phase four, thus raising questions for future research. The analysis and discussion in this paper therefore demonstrate that port development in LAC, as in other port systems, has been driven first by significant and continued growth of container traffic. Strategies of liner shipping companies have evolved towards a wide implementation of hub-and-spoke networks, leading to patterns of concentration exhibiting significant effects of path dependence. However, the contingency of both private investment and public planning approval have been found to play an important role in port development, supporting newly-emergent port hierarchies. The work in this paper takes these notions forward by underscoring the spatio-temporal aspects of port system evolution, allied to the importance of a systemic view in order to identify where critical moments are turned into critical junctures where port actors can overcome path dependence. This paper has been able to identify some characteristics of these moments through an analysis of the LAC port system, but is necessarily limited by the focus on this geographical scale. More disaggregated research is, therefore, required in order to take these findings forward in more detail. Analysis of liner connections, beyond the scope of this paper, is also needed in future to explore the role of shipping lines in supporting the rise of second level hubs as established in this paper.

A resulting hypothesis is that the critical moments identified in this case will also be found in other contexts. The rise of secondary ports has already been identified in recent research (e.g. Wang and Ng, 2011, in China; Wilmsmeier and Monios, 2013, in the UK), yet their emergence and location choice has not been explained necessarily by natural location advantages (as previously dominant ports were), suggesting that they are driven to a large degree by institutional adaptation, which enables them to compete against an incumbent port, not an easy task. It is recognized that to some extent these factors will be unique to each port system (cf. Ng and Pallis, 2011); nevertheless, some of the key facets relating to port 
devolution, the introduction of the private sector to port operations but most importantly, the ongoing relation between the private operators and the changing regulatory system, have been revealed in this case. Port devolution is not always a simple procession from public to private but can result rather in a different kind of system, one that is not necessarily better than the previous one and could even lock in a new path dependence. This important topic requires further disaggregated research.

When applying any universal model to a region, there will always be some specific local factors that are unique to that case. In the case of LAC, it is the different rates of port devolution in different countries within what is after all a very large port system comprised of several sub systems. That is why the institutional theory is required to explore in a more structured way the influences on the transition from phase three to four. The way in which institutions in the region are being transformed could have a determinative effect on the success of the various projects and strategies such as new ports or expansion of old ones. This paper has identified and systematized some of these institutional processes, but further disaggregated research on specific cases will be required to understand the effect of port devolution in LAC on changes in the evolution of this port system.

A number of questions requiring disaggregated research emerge from the findings in this paper. As the LAC port system can generally be categorized as evolving from concentration to deconcentration, what implications does this have for the policies of individual countries within the region? What is the role of shipping lines in driving the emergence of new and secondary ports? How far does economic development contribute not just to throughput growth but to a geographical diversification of the growth of container ports? Are other economic or institutional variables playing a role in the emergence of these ports?

The approach taken in this paper builds on previous work in the field by providing insights into the constraining factors of maritime networks and the associated implications for trade development. The conceptualisation of port development advanced in this paper underlines the necessity for decision makers to develop a clear understanding of its complexity; such knowledge can potentially reduce risks and enable a view of port development that incorporates the wider impacts on the economic, social and transport systems. At the same time, such a conceptualisation enables decision makers to reflect critically on their own role as a factor in port development. 


\section{References}

Alphaliner. (2012). Evolution of carriers fleets. Available at: http://www.alphaliner.com/liner2/research_files/liner_studies/misc/AlphalinerTopCarrier s-2012.pdf Accessed 25th September 2013.

Barke, M. 1986. Transport and Trade; Conceptual Frameworks in Geography, Edinburgh: Oliver \& Boyd.

Bird, J. 1963. The Major Seaports of the United Kingdom. London: Hutchinson \& Co.

Cullinane, KPB and Khanna, M. 2000. Economies of scale in large containerships: optimal size and geographical implications, Journal of Transport Geography, 8, 181-195.

Cullinane, KPB and Wilmsmeier, G. 2011. The Contribution of the Dry Port Concept to the Extension of Port Life Cycles. In: Böse, J. W., ed., 2011. Handbook of Terminal Planning. New York: Springer.

Drewry Shipping Consultants. (2012). Global Container Terminal Operators Annual Review and Forecast 2012. London: Drewry Publishing.

Drewry Shipping Consultants. (2013). Container Market - 2012/13. Annual Review and Forecast. London: Drewry publishing.

Ducruet, C., Roussin, S., Jo, J-C. 2009. Going west? Spatial polarization of the North Korean port system. Journal of Transport Geography. 17 (5): 357-368.

Fagerholt K. 2004. A computer-based decision support system for vessel fleet scheduling Experience and future research. Decision Support Systems 37(1), 35-47.

Fleming, D. K., Hayuth, Y., 1994, Spatial characteristics of transportation hubs: centrality and intermediacy. Journal of Transport Geography, 2, 3-18.

Frémont, A., Soppé, M., 2007. Northern European range: Shipping line concentration and port hierarchy. In Ports, Cities and Global Supply Chains, Edited by: Wang, J, Olivier, D, Notteboom, T and Slack, B. 105-120. Aldershot: Ashgate.

Hayuth, Y. 1981. Containerization and the load center concept. Economic Geography, 57: $160-176$.

Hoyle, BS. 1968. East African seaports: an application of the concept of 'anyport'. Transactions \& Papers of the Institute of British Geographers, 44.163-183.

Jacobs, W and Notteboom, TE. 2011. An evolutionary perspective on regional systems: The role of windows of opportunity in shaping seaport competition, Environment \& Planning A, 43(7), pp.1674-1692.

Lee, S.W., Song, D.W., Ducruet, C., 2008. A tale of Asia's world ports: the spatial evolution in global hub port cities. Geoforum 39 (1): 372-395. 
Magala, M and Sammons, A. 2008. A new approach to port choice modelling. Maritime Economics \& Logistics, 10, (1-2), pp. 9-34

Marx, K., Engels, F. (1850). Address of the Central Committee to the Communist League. Available at: http://www.marxists.org/archive/marx/works/1847/communist-league/1850ad1.htm Accessed 16th May 2014.

Maturana, H and Varela, F. 1980. Autopoiesis and Cognition: the Realization of the Living. Robert S. Cohen and Marx W. Wartofsky (Eds.), Boston Studies in the Philosophy of Science 42. Reidel Publishing Co.

Mingers, J. 1994. Self-Producing Systems. Kluwer Academic/Plenum Publishers

Monios, J and Wilmsmeier, G. 2012. Giving a direction to port regionalisation. Transportation Research Part A: Policy and Practice, 46: 1551-1561.

Monios, J and Wilmsmeier, G. 2012. Port-centric logistics, dry ports and offshore logistics hubs: Strategies to overcome double peripherality? Maritime Policy \& Management, 39: 207-226.

Ng, AKY. and Pallis, AA. 2010. Port governance reforms in diversified institutional frameworks: generic solutions, implementation asymmetries. Environment \& Planning A, 42 (9) pp.2147-2167.

Nijkamp, P. 1998, European Regional Development Policies and Foreign Direct Investments. Seier Research Memoranda. The Netherlands

Notteboom, TE. 2005. The peripheral port challenge in container port systems. In International Maritime Transport: Perspectives, Edited by: Leggate, H, McConville, J and Morvillo, A. 173-188. London: Routledge.

Notteboom, T. E. 2009. Path dependency and contingency in the development of multi-port gateway regions and multi-port hub regions. In: Notteboom, T., Ducruet, C., de Langen, P., (Eds.). Ports in Proximity; Competition and Coordination Among Adjacent Seaports. Ashgate: Aldershot.

Notteboom, TE and Rodrigue, J. 2005. Port regionalization: Towards a new phase in port development. Maritime Policy \& Management, 32: 297-313.

Olivier, D. and Slack, B. 2006. Rethinking the port. Environment \& Planning A, 38 (8) pp.1409-1427.

Pérez Salas, G., Ulloa, M. 2010. Port throughputs in Latin America and the Caribbean in 2009 and the first half of 2010, October 2010, Fal Bulletin, No. 290, ECLAC, Santiago, Chile. 
Rimmer, PJ. 1967. The search for spatial regularities in the development of Australian seaports 1861 - 1961/2. Geograkiska Annaler, 49 pp.42-54.

Robinson, R. 2002. Ports as elements in value-driven chain systems: The new paradigm. Maritime Policy \& Management, 29: 241-255. [Taylor \& Francis Online], [CSA]

Rodrigue, J-P and Notteboom, TE 2010. Foreland-based regionalization: Integrating intermediate hubs with port hinterlands. Research in Transportation Economics, 27: 1929.

Sánchez RJ and Perrotti DE. 2012. Looking into the future: big full containerships and their arrival to South American ports. Maritime Policy and Management, Volume 39, Issue 6, 2012.

Sánchez, R. J., Ulloa, M., 2007. Port activity and port capacity management in Latin America and the Caribbean 2006, Issue $\mathrm{N}^{\circ}$ 252, August 2007, Fal Bulletin, No. 252, ECLAC, Santiago, Chile.

Sanchez, RJ and Wilmsmeier, G. 2006. The river plate basin - A comparison of port devolution processes on the East Coast of South America. Research in Transportation Economics, 17: 185-205.

Slack, B and Wang, JJ. 2002. The challenge of peripheral ports: An Asian perspective. Geojournal, 56: 159-166.

Strambach S. 2010, Path dependency, path plasticity - the co-evolution of institutions and innovation. The German business software industry. In: Boschm, RA and Martin, R (eds). Handbook for Evolutionary Economic Geography, p 406-431. Cheltenham. Edgar Elgar

Swyngedouw, E. 1992. Territorial organization and the space/technology nexus. Transactions of the Institute of British Geographers, 17: 417-433.

Taaffe, EJ, Morrill, RL \& Gould, PR. 1963. Transport expansion in underdeveloped countries: a comparative analysis. Geographical Review, 53 (4) pp.503-529.

UNCTAD, 1992. Development and improvement of ports: the principles of modern port management and organisation. Geneva, Switzerland: UNCTAD.

Wang, C., Ducruet, C. 2012. New port development and global city making: emergence of the Shanghai-Yangshan multi-layered gateway hub. Journal of Transport Geography. 25: 58-69.

Wang, J. J., Ng, A. K. Y. 2011. The geographical connectedness of Chinese seaports with foreland markets: a new trend? Tijdschrift voor Economische en Sociale Geografie. 102 (2): 188-204. 
Wilmsmeier, G. 2013. Liner Shipping Markets, Networks and Strategies. The implications for port development on the West Coast of South America. The case of Chile ITF, Discussion Paper No 2013-22, November 2013

Wilmsmeier, G; Martinez-Zarzoso, I; Fiess, N. 2011 Regional hub port development - the case of Montevideo, Uruguay. International Journal of Shipping and Transport Logistics, Volume 3, Number 4, pp. 475-493.

Wilmsmeier, G. and Monios, J. 2013. Counterbalancing peripherality and concentration: an analysis of the UK container port system, Maritime Policy \& Management, 40(2), pp.

Wilmsmeier, G and Sanchez, R. 2010. Evolution of shipping networks: Current challenges in emerging markets. Zeitschrift fuer Wirtschaftsgeographie, 3/4: 180-193. 


\section{Appendix}

Table 2. Throughput (TEU) and concentration at LAC coastal ranges 1997, 2005, 2012

\begin{tabular}{|c|c|c|c|c|c|}
\hline Sub-region & Data & 1997 & 2005 & 2012 & $\begin{array}{c}\text { Growth } \\
1997-2012\end{array}$ \\
\hline \multirow{5}{*}{ CARIB } & Throughput (all ports) & $3,507,509$ & $6,559,985$ & $7,942,552$ & \multirow{5}{*}{$126 \%$} \\
\hline & No. of ports > 100,000 TEU & 5 & 9 & 12 & \\
\hline & Gini (ports > 100,000 TEU) & 0.52 & 0.47 & 0.47 & \\
\hline & HHI (ports > 100,000 TEU) & 0.428 & 0.209 & 0.154 & \\
\hline & HHI minimum & 0.200 & 0.111 & 0.083 & \\
\hline \multirow{5}{*}{ ECCA } & Throughput (all ports) & $1,857,732$ & $3,831,264$ & $6,136,975$ & \multirow{5}{*}{$230 \%$} \\
\hline & No. of ports > 100,000 TEU & 5 & 5 & 5 & \\
\hline & Gini (ports > 100,000 TEU) & 0.35 & 0.45 & 0.46 & \\
\hline & HHI (ports > 100,000 TEU) & 0.283 & 0.378 & 0.397 & \\
\hline & HHI minimum & 0.200 & 0.200 & 0.200 & \\
\hline \multirow{5}{*}{ ECM } & Throughput (all ports) & 600,315 & $1,034,838$ & $1,455,927$ & \multirow{5}{*}{$143 \%$} \\
\hline & No. of ports > 100,000 TEU & 2 & 2 & 2 & \\
\hline & Gini (ports > 100,000 TEU) & 0.22 & 0.16 & 0.08 & \\
\hline & HHI (ports > 100,000 TEU) & 0.596 & 0.549 & 0.513 & \\
\hline & HHI minimum & 0.500 & 0.500 & 0.500 & \\
\hline \multirow{5}{*}{ ECSA } & Throughput (all ports) & $3,228,464$ & $7,425,305$ & $10,936,591$ & \multirow{5}{*}{$239 \%$} \\
\hline & No. of ports > 100,000 TEU & 7 & 12 & 17 & \\
\hline & Gini (ports > 100,000 TEU) & 0.43 & 0.45 & 0.47 & \\
\hline & HHI (ports > 100,000 TEU) & 0.257 & 0.163 & 0.130 & \\
\hline & HHI minimum & 0.143 & 0.083 & 0.059 & \\
\hline \multirow[t]{2}{*}{ NCSA } & Throughput (all ports) & $1,013,194$ & $1,988,697$ & $4,247,205$ & \multirow[t]{2}{*}{$319 \%$} \\
\hline & No. of ports > 100,000 TEU & 3 & 3 & 6 & \\
\hline
\end{tabular}




\begin{tabular}{|c|c|c|c|c|c|}
\hline & Gini (ports > 100,000 TEU) & 0.12 & 0.18 & 0.54 & \\
\hline & HHI (ports > 100,000 TEU) & 0.352 & 0.380 & 0.372 & \\
\hline & HHI minimum & 0.333 & 0.333 & 0.167 & \\
\hline \multirow{5}{*}{ WCCA } & Throughput (all ports) & 134,058 & $1,102,128$ & $4,082,337$ & \multirow{5}{*}{$2945 \%$} \\
\hline & No. of ports > 100,000 TEU & 0 & 3 & 4 & \\
\hline & Gini (ports > 100,000 TEU) & 0.00 & 0.38 & 0.60 & \\
\hline & HHI (ports > 100,000 TEU) & 0.000 & 0.510 & 0.702 & \\
\hline & HHI minimum & 0.000 & 0.333 & 0.250 & \\
\hline \multirow{5}{*}{ WCM } & Throughput (all ports) & 302,540 & $1,098,638$ & $3,422,170$ & \multirow{5}{*}{$1031 \%$} \\
\hline & No. of ports > 100,000 TEU & 1 & 2 & 3 & \\
\hline & Gini (ports > 100,000 TEU) & N/A & 0.37 & 0.37 & \\
\hline & HHI (ports > 100,000 TEU) & N/A & 0.771 & 0.486 & \\
\hline & HHI minimum & N/A & 0.500 & 0.333 & \\
\hline \multirow{5}{*}{ WCSA } & Throughput (all ports) & $2,008,677$ & $3,954,903$ & $8,046,699$ & \multirow{5}{*}{$301 \%$} \\
\hline & No. of ports > 100,000 TEU & 5 & 8 & 12 & \\
\hline & Gini (ports > 100,000 TEU) & 0.11 & 0.33 & 0.46 & \\
\hline & HHI (ports > 100,000 TEU) & 0.208 & 0.171 & 0.144 & \\
\hline & HHI minimum & 0.200 & 0.125 & 0.083 & \\
\hline
\end{tabular}

